NISTIR 6945 Rev.

\title{
REFERENCE
}

\section{Refrigerator Energy Consumption Test Results using the United States Department of Energy and International Organization for Standardization Test Procedures}

David A. Yashar

U.S DEPARTMENT OF COMMERCE National Institute of Standard and Technology Building Environment Division Building and Fire Research Laboratory Gaithersburg, MD 20899-8631

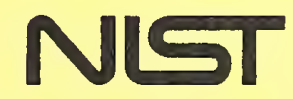

National Institute of Standards and Technology Technology Administration, U.S. Department of Commerce

QC 

NISTIR 6945 Rev.

\section{Refrigerator Energy Consumption Test Results using the United States}

\section{Department of Energy and International Organization for Standardization Test Procedures}

David A. Yashar

U.S DEPARTMENT OF COMMERCE National Institute of Standard and Technology Building Environment Division Building and Fire Research Laboratory Gaithersburg, MD 20899-8631

Revised March 2003

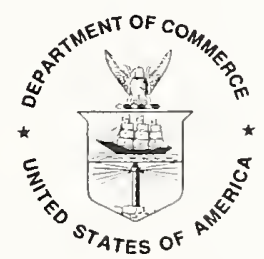

U.S. Department of Commerce Donald L. Evans, Secretary 



\title{
Refrigerator Energy Consumption Test Results using the United States Department of Energy and International Organization for Standardization Test Procedures
}

\author{
David A. Yashar \\ National Institute of Standards and Technology \\ Gaithersburg, MD 20899
}

\begin{abstract}
This investigation compares the energy consumption ratings obtained for refrigerators using the Association of Home Appliance Manufacturers (AHAM) HRF-1 test procedure, as adopted by the United States Department of Energy (DOE), and the International Organization for Standardization (ISO) equivalent test procedures (ISO 8561 and ISO 7371). Tests were performed on four different units according to both the DOE test procedure and the appropriate ISO test procedure. These units included two household kitchen-type, automatic defrost refrigerator-freezers, one of each body style that is prevalent in the US (one unit with the top mounted freezer compartment and the other unit with the refrigerator and freezer compartments in a side-by-side configuration). A top mount, automatic defrost refrigerator-freezer which employs many novel energy saving devices and techniques was also tested. The final unit tested was a manual defrost refrigerator, as this is a popular design in many European countries. The results showed that the energy consumption ratings found for automatic defrost refrigerator-freezers under the DOE tests were $25.0 \%$ to $29.4 \%$ higher than the results obtained with the ISO tests. For the manual defrost model, the tests showed that the DOE test produced a value which was $33 \%$ higher than that found by the ISO test. The results were then compared to the findings of a previous study conducted at the University of Auckland.
\end{abstract}

Keywords: Refrigerator, AHAM HRF-1, ISO 8561, ISO 7371, Energy consumption test 


\section{Acknowledgement}

This study was sponsored by the United States Department of Energy. The author would like to thank Lindsey Roke of Fisher \& Paykel and Dr. Pradeep Bansal of the University of Auckland for their assistance on this project. Also, special thanks to Steve Church of Whirlpool for supplying test units for this study and for his review of this report. Finally, the author would like to thank Dr. Mark Kedzierski, Dr. Piotr Domanski, and Dr. W. Vance Payne of the National Institute of Standards and Technology for all of their assistance with this project.

Disclaimer: The policy of the National Institute of Standards and Technology is to use the International System of Units (metric units) in all of its publications. However, the test standards that were used in this study require that certain values be presented in specific non-SI units, and have thereby come to be the industry standard. It is for this reason that the energy consumption of the test subjects are presented in units of $[(\mathrm{kW} \cdot \mathrm{h}) / \mathrm{d}]$ throughout this report.

Certain trade names or company products are mentioned in the text to specify adequately the experimental procedure and equipment used. In no case does such identification imply recommendation or endorsement by the National Institute of Standards and Technology, nor does it imply that the equipment is the best available for the purpose. 


\section{Table of Contents}

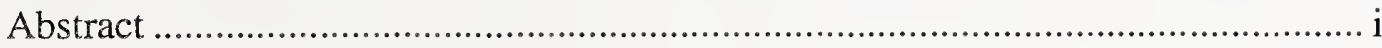

Acknowledgement ............................................................................................ ii

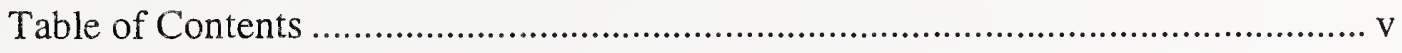

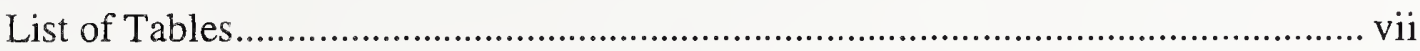

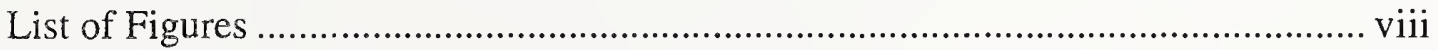

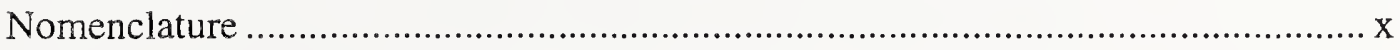

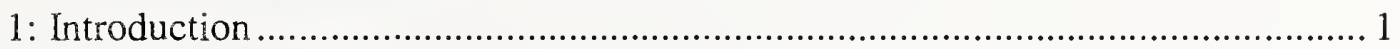

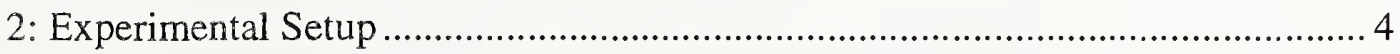

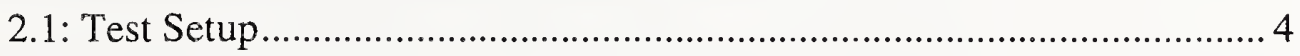

2.2: Instrumentation and Data Acquisition ................................................. 4

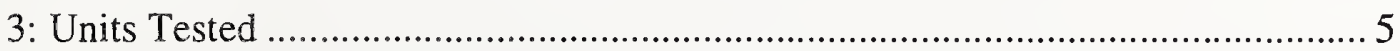

4: Experimental Procedure and Test Conditions................................................. 7

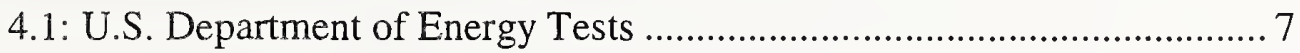

4.2: International Standards Organization (ISO) Tests ................................. 8

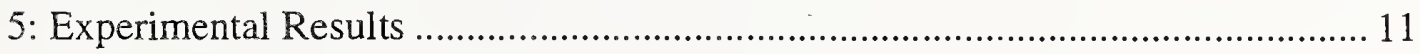

5.1: Side-By-Side Domestic Automatic Defrost Refrigerator-Freezer ............ 11

5.2: Top Mounted Domestic Automatic Defrost Refrigerator-Freezer............ 12

5.3: Top Mounted Automatic Defrost Refrigerator with Energy Saving

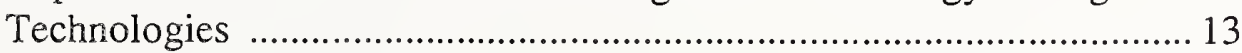

5.4: Manual Defrost Refrigerator .............................................................. 15

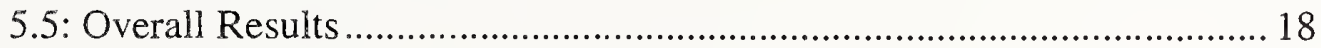

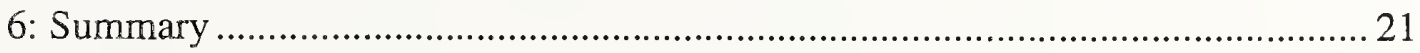

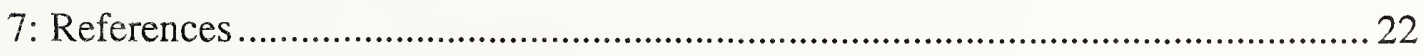

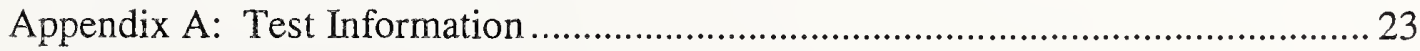

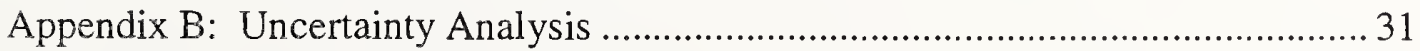




\section{List of Tables}

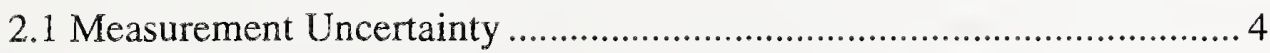

4.1 Required storage temperatures for ISO tests ...................................

4.2 Specifications for load packages required for ISO tests ........................ 10

5.1 Test results for side-by-side refrigerator-freezer.................................. 11

5.2 Test results for top mounted refrigerator-freezer ................................. 12

5.3 Test results for top mounted refrigerator-freezer with energy

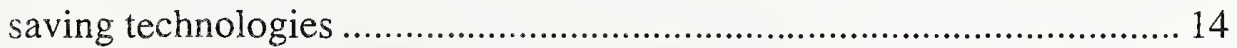

5.4 Test results for manual defrost refrigerator ............................................ 16

B.1 Uncertainty Analysis for Side-By-Side Refrigerator-Freezer ...............223

B.2 Uncertainty Analysis for Top Mounted Refrigerator-Freezer ................. 23

B.3 Uncertainty Analysis for Top Mounted Refrigerator-Freezer with Energy Saving Technologies........................................................... 24

B.4 Uncertainty Analysis for Manual Defrost Refrigerator .......................... 24 


\section{List of Figures}

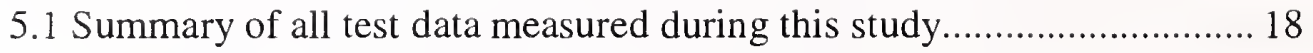

5.2 Comparison of test results to correlation for automatic defrost units .... 19

A.1 Side-by-side domestic automatic defrost refrigerator-freezer

Prepared for DOE tests.

A.2 Side-by-side domestic automatic defrost refrigerator-freezer

Prepared for ISO tests

A.3 Side-by-side domestic automatic defrost refrigerator-freezer

Plot of typical energy usage during defrost sequence 24

A.4 Side-by-side domestic automatic defrost refrigerator-freezer

Plot of typical energy usage during steady state operation

A.5 Top mount domestic automatic defrost refrigerator-freezer

Prepared for DOE tests

A.6 Top mount domestic automatic defrost refrigerator-freezer

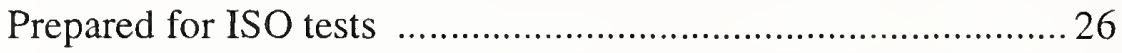

A.7 Top mount domestic automatic defrost refrigerator-freezer

Plot of typical energy usage during defrost sequence ................26

A.8 Top mount domestic automatic defrost refrigerator-freezer

Plot of typical energy usage during steady state operation

A.9 Top mount technologically advanced refrigerator-freezer

Prepared for DOE tests.

A.10 Top mount technologically advanced refrigerator-freezer

Prepared for ISO tests 28

A.11 Top mount technologically advanced refrigerator-freezer

Plot of typical energy usage during defrost sequence 28

A.12 Top mount technologically advanced refrigerator-freezer

Plot of typical energy usage during steady state operation

A.13 Manual defrost refrigerator prepared for DOE tests ......................... 29

A.14 Manual defrost refrigerator prepared for ISO tests .......................... 30

A.15 Manual defrost refrigerator

Plot of typical energy usage during steady state operation ........ 30 


\section{Nomenclature}

CT

COP

$\mathrm{COP}_{\text {Carmot }}$

$\Delta T$

$\Delta T_{\text {cond }}$

$\Delta T_{\text {evap }}$

$E_{R, \text { max }}$

$E_{R}$

n

Qevap

$\mathrm{R}$

$\mathrm{t}_{\mathrm{cm}}$

$T_{\text {crind }}$

$T_{\text {evap }}$

$\mathrm{t}_{\mathrm{m}}$

$T_{F}$

$T_{\text {ref }}$

UA

W

Subscripts

1,2

A, B
Time between consecutive defrost cycles

Coefficient of Performance

Theoretical Carnot Coefficient of Performance

Temperature difference between ambient and internal temperatures

Temperature difference between ambient and condensing temperatures

Temperature difference between freezer and evaporating temperatures

Maximum uncertainty of energy consumption

RMS uncertainty of energy consumption

Number of independent measurements

Cooling capacity from the evaporator

Uncertainty of a given quantity

Refrigerator cellar compartment temperature, ISO test procedures

Refrigerant condensing temperature

Refrigerant evaporating temperature

Refrigerator compartment temperature, ISO test procedures

Coldest internal compartment temperature, Bansal and Krüger

Refrigerated compartment reference temperature

Overall heat transfer coefficient of refrigerator cabinet

Energy consumption

Denotes specific test measurement

Denotes specific test procedure, Bansal and Krüger 



\section{1: Introduction}

As appliance manufacturers expand their businesses into a global market, it becomes more desirable to develop an international test procedure for the rating of their products. An international test procedure would allow manufacturers to reduce their use of valuable resources required to perform different tests for each appliance. Although the intent of each nation's test procedures is the same for a given product, the differing needs and preferences of these nations have resulted in differences in the test procedures.

This study is concerned with the energy rating procedures for refrigerators. It is of particular interest to examine the energy performance ratings obtained for refrigerators when tested by the procedures accepted by the United States Department of Energy (DOE) and by the International Organization for Standardization (ISO). It is expected that these test procedures will produce very different results, due to the differences between the procedures. Namely, the main differences are as follows:

1) Ambient temperature. The ambient test conditions stipulated by the DOE procedure are much warmer than those required for the ISO test procedures. This is the most significant difference between the test procedures and will often result in higher measured energy consumption for the DOE test procedure.

2) Freezer loading. There are also differences in the loading of these units. For automatic defrost refrigerators, the freezer compartment is filled with loading packages for the ISO test procedure and is empty for the DOE test procedure. For manual defrost models, both the ISO and DOE test procedures require load packages, however fewer packages are needed for the DOE test. Also, the composition and geometry of the packages are different between the two standards.

3) Target temperatures. All energy consumption tests require that a certain target temperature be maintained within the unit over a measurement period. Each test procedure outlines the required target temperatures according to the standards' classification of the unit. Unfortunately, there are also differences regarding the classification of refrigerators, which sometimes make direct comparison of the performance rather difficult.

4) Temperature Measurements. The last major difference is the manner in which the temperatures are recorded. The DOE test bases the results on the average of the measured temperatures in the compartment, whereas the ISO test procedures prefer to base the results on the maximum compartment temperature.

A study was conducted at the University of Auckland by Bansal and Krüger (1995), which compared the energy consumption of four different refrigerators as tested by five separate test procedures. Each of the units in their study used the phased out refrigerant CFC-12; however, their study offers the best basis of comparison to the current study. The results of their study showed that they were able to correlate, reasonably well, the energy consumption of a refrigerator as tested by different procedures. They accomplished this by calculating a theoretical Carnot Coefficient of Performance (COP) for each test procedure based on information from the temperatures outlined in the 
various procedures. They then used this information to formulate multipliers that convert one test result to another.

The COP of the Carnot cycle is defined as the ratio of the cooling power to the amount of work input to the compressor. It is equal to the ratio of the evaporating temperature of the refrigerant to the temperature difference between the condensing and evaporating temperatures, in absolute temperatures.

$$
\mathrm{COP}_{\text {Camot }}=\frac{T_{\text {evap }}}{T_{\text {cond }}-T_{\text {evap }}}
$$

Bansal and Krüger used the concept of the Carnot cycle to estimate the COP of the refrigerator. Since the evaporating and condensing temperatures are unknown, they assumed a constant temperature difference between the evaporating temperature and the coldest refrigerated compartment temperature, $\Delta T_{\text {evap }}$, and also a constant temperature difference between the condensing temperature and the ambient temperature, $\Delta T_{\text {cond }}$. This allowed them to estimate the $\mathrm{COP}$ as follows:

$$
\mathrm{COP}=\frac{T_{F}-\Delta T_{\text {evap }}}{\left(T_{\text {ambient }}+\Delta T_{\text {cond }}\right)-\left(T_{F}-\Delta T_{\text {evap }}\right)}
$$

For their study, they used values of $7{ }^{\circ} \mathrm{C}$ for $\Delta T_{\text {cond }}, 15^{\circ} \mathrm{C}$ for $\Delta T_{\text {evap }}$ in the case of allrefrigerators, and $7^{\circ} \mathrm{C}$ for $\Delta T_{\text {evap }}$ in the case of refrigerator-freezers. Although these temperature differences may seem large, these values were selected because the units tested in their study do not employ forced convection to drive this heat transfer.

They also assigned a temperature difference parameter, $\Delta T$, to each unit under a given standard; where this parameter is the difference between the ambient temperature and the compartment air. Their correlation was of the form:

$$
W_{A}=\left(\frac{C O P_{B}}{C O P_{A}} \sqrt{\frac{\Delta T_{A}}{\Delta T_{B}}}\right) W_{B}
$$

Where the subscripts $\mathrm{A}$ and $\mathrm{B}$ denote specific test procedures and the variable $\mathrm{W}$ denotes the energy consumption value obtained through testing.

Although the units used in the study at the University of Auckland are somewhat different from those used in this report, the principles applied to derive the parameters in their correlation are general to any vapor compression cycle. These parameters are inherent to the basic thermodynamic principles used in a refrigerator, and they provide a useful tool for comparison between different operating conditions. Therefore, this correlation was used as a basis for comparison to the data presented in this report. 
The following sections present the experimental apparatus, the units tested, the experimental procedures, and the results of the energy consumption tests as measured in accordance with the procedures outlined by the DOE and the ISO. Additional test information, photographs, energy plots and uncertainty analysis are included in the Appendices. 


\section{2: Experimental Setup}

\section{1: Test Setup}

Two identical test cells were constructed in the laboratory in order to simultaneously measure the energy consumption of two refrigerators. Each test cell consisted of a nonthermally conductive platform upon which the refrigerator stood, a wall that stands adjacent to the rear of the refrigerator, and two sidewalls that partially enclosed the sides of the refrigerator. All faces of the test cells were painted dull black to minimize the radiant heat to and from the refrigerator during testing. Although similar, the dimensions of the test cell varied according to the test performed and the refrigerator being tested; therefore the cells were constructed so that the walls could be easily moved between tests.

The test cells were placed in an environmental chamber, which was large enough to house two test cells and all of the necessary data acquisition hardware. This environmental chamber is capable of providing a controlled ambient temperature and humidity over long periods of time with little supervision, as was necessary due to the lengthy test periods associated with these standards.

\section{2: Instrumentation and Data Acquisition}

Temperature data were gathered using a personal computer and a multiplexed data acquisition unit. Depending on the test type and the refrigerator, between 11 and 17 temperature locations per test cell were monitored using T-type thermocouples.

The electrical energy input was monitored using a separate personal computer dedicated to a digital power meter. By using a separate computer to monitor the energy, no information was lost due to the periodic multiplexing of other data acquisition devices. All temperatures were sampled once every $30 \mathrm{~s}$, and the power was sampled once per second. Table 2.1 lists the measured quantities and the uncertainty associated with $95 \%$ confidence.

Table 2.1 Measurement Uncertainty

\begin{tabular}{|c|c|c|}
\hline Measured Quantity & Measurement Device & $\begin{array}{c}\text { Uncertainty at 95 \% } \\
\text { confidence }\end{array}$ \\
\hline Temperature & Thermocouples & $\pm 0.3^{\circ} \mathrm{C}\left(0.5^{\circ} \mathrm{F}\right)$ \\
\hline Humidity & Chilled mirror hygrometer & $\pm 2{ }^{\circ} \mathrm{C}\left(4^{\circ} \mathrm{F}\right)$ dew point \\
\hline Power & Watt-meter & $\pm 0.3 \%$ of reading \\
\hline Time & Personal Computer & $\pm 1 \mathrm{~s} / \mathrm{d}$ \\
\hline
\end{tabular}




\section{3: Units Tested}

Four refrigerators were selected for participation in this study. Two of these refrigerators were domestically manufactured, automatic defrost, "Refrigerator-Freezers" as classified by the US DOE classification system. The third unit selected for this study was purchased overseas, as it's unique, energy saving technologies and algorithms were of interest to this study. This refrigerator is also categorized as an automatic defrost, "Refrigerator-Freezer" by the U.S. DOE classification system. The fourth refrigerator was manufactured domestically, but is a manual defrost model that is classified as a "Basic Refrigerator" by the US DOE system. All refrigerators tested in this study used HFC-134a refrigerant.

The first refrigerator examined in this study is a side-by-side refrigerator-freezer. This refrigerator follows a periodic automatic defrost sequence to remove ice from its evaporator. It is equipped with an automatic icemaker and a through-the-door ice and water dispenser. This model was manufactured in the United States, for the intended sale in the United States.

The second refrigerator examined in this study is a top-mounted refrigerator-freezer, as the freezer compartment is located above the refrigerator compartment. This model also follows a periodic automatic defrost sequence, and has an automatic icemaker. It was also manufactured in the United States, for the intended sale in the United States.

The third refrigerator examined in this study is a top-mounted, automatic defrost refrigerator-freezer. This unit was purchased from a manufacturer in New Zealand and shipped to the US, as its unique features are intriguing to this study. This model is typically manufactured for Asian and south pacific markets; therefore, it was specially built for this study with a compressor motor that operates on $115 \mathrm{~V}, 60 \mathrm{~Hz}$ electricity. There are two main features that are employed in this unit to allow more efficient use of its energy. These include:

1. Intelligent Defrost Sequence. For a typical defrost cycle, some measurement is taken and is used to trigger a sequence of events (this can include a number of devices used to measure the amount of frost that has accumulated on the evaporator or the amount of time that the compressor has operated). This event that triggers a defrost cycle usually occurs during a period of operation of the compressor. When the triggering mechanism is activated, the compressor is turned off and a heater is turned on. When the heater has completed its task, it is turned off and after a short delay the compressor begins to operate to return the evaporator and compartment to their operational temperatures. The sequence used in this model adds a period of non-operation after the defrost cycle is triggered, but before the heater turns on. This allows the evaporator to be warmed up by the air in the compartment, so that the heater does not have to operate for as long of a period of time. Domestic manufacturers have begun to adopt this defrost sequence. 
2. Variable Speed Fans and Ducts. In a typical household refrigerator, fans and ducts direct the airflow over the evaporator and deliver it to the compartments of the refrigerator. A feature that is unique to this refrigerator is the ductwork to each compartment has its own dedicated variable speed fan. In addition, it also has a more complex system of temperature measurement and decision-making circuitry than typical refrigerators. These features provide this unit with the ability to asses the cooling demand in the cabinets and direct the appropriate amount of cold air to those locations. The purpose of this feature is to accurately control the compartment temperatures independently of other compartments.

Finally, the fourth refrigerator is a small "basic refrigerator." It was manufactured in the United States for use as a secondary, under-the-counter type refrigerator. It does not employ an automatic defrost algorithm, rather it must be periodically defrosted manually. A small freezer compartment (approximately $22 \mathrm{~L}, 0.78 \mathrm{ft}^{3}$ ) is located at the upper portion of the refrigerated compartment. The walls of the freezer compartment are refrigerated surfaces that cool the refrigerator compartment by natural convection. 


\section{4: Experimental Procedure and Test Conditions}

For each measurement, the refrigerator was placed on the test cell platform and the walls were adjusted according to the procedure. If a thermal load was required for a particular test, load packages were loaded into the freezer and refrigerator compartment. Three thermocouples were placed on each side of the refrigerator in accordance with each test procedure to monitor the ambient conditions. Thermocouples were placed inside the refrigerator compartments (number and location to be in accordance with applicable test procedures). Automatic ice makers were turned off during all tests. Finally, the refrigerator's electrical cord was plugged into the digital power meter so that its energy use could be recorded.

For all test situations and stabilization periods, the environmental chamber was maintained within $0.3^{\circ} \mathrm{C}\left(0.5^{\circ} \mathrm{F}\right)$ of the target dry bulb and $2.0^{\circ} \mathrm{C}\left(3.6^{\circ} \mathrm{F}\right)$ dew point temperatures. Since there were two test cells used in this laboratory, it was possible to record the data from one unit while the other would undergo its stabilization period.

\section{1: U.S. Department of Energy Tests}

The DOE follows the test procedure outlined by the Association of Home Appliance Manufacturers (AHAM), termed HRF-1 Household Refrigerators/Household Freezers. According to this test procedure, the three automatic defrost refrigerators would be classified as "Refrigerator-Freezers" and the manual defrost refrigerator would be classified as a "Basic Refrigerator," which slightly modifies some of the parameters associated with the measurements.

\section{Refrigerator-Freezer Test Procedure}

For the measurements on Refrigerator-Freezers, the freezer compartment is left empty, except for the thermocouples. There are at least three, but as many as five thermocouples in the freezer compartment; three thermocouples were used for the domestic top-mount unit and for the foreign-made unit while five thermocouples were used in the side-by-side unit. Three thermocouples were also placed in the refrigerator compartments of each of these units.

The thermostat was set to the median setting for each compartment of the refrigeratorfreezer, and it was operated in an environment held at a constant $32.2^{\circ} \mathrm{C}\left(90^{\circ} \mathrm{F}\right)$ until steady state operation was achieved. There is no specified humidity required for these tests, however it was held at a constant $20.0^{\circ} \mathrm{C}\left(68^{\circ} \mathrm{F}\right)$ dew point, which corresponds to $50 \%$ relative humidity.

For the DOE test procedure, the recorded compartment temperature is the average of the measured temperature from each thermocouple; where the measured temperature is the time averaged temperature from a thermocouple over the duration of the test period.

The temperatures and electrical energy were then recorded over the duration of the test period. The test period encompasses one defrost sequence and the entire steady operation 
between two consecutive defrost sequences. Alternatively, if the defrost sequences are separated by more than $14 \mathrm{~h}$ of compressor run time; then the classification of this unit is termed "Long Time Automatic Defrost." For this type of refrigerator, the test period is broken into two parts, one part demonstrating steady operation and one part demonstrating the defrost sequence. The first part must be at least $3 \mathrm{~h}$ long and encompass a whole number of compressor on/off cycles, and the second part must record all of the events associated with the defrost sequence.

The target temperature for refrigerator-freezers is $-15^{\circ} \mathrm{C}\left(5^{\circ} \mathrm{F}\right)$, measured in the freezer compartment. If the measured freezer compartment temperature for the first test is warmer than this, then the thermostat(s) is (are) set to the coldest setting for a second measurement. Conversely, if the measured temperature in the freezer compartment is colder than the target temperature, then the thermostat(s) is (are) set to the warmest setting for a second measurement.

After two measurements have been taken, a plot of energy consumption versus freezer temperatures is generated and a linear fit is produced. The energy consumption value is found from this fit as the energy consumption that would produce a temperature of $-15^{\circ} \mathrm{C}$ $\left(5^{\circ} \mathrm{F}\right)$, measured in the freezer compartment.

\section{$\underline{\text { Basic Refrigerator Test Procedure }}$}

The procedure used for a basic refrigerator is similar to that of a refrigerator-freezer; however, there are three major differences.

The first difference is that the freezer compartment of a basic refrigerator is to be loaded with packages to act as thermal ballast. The load packages are to be packages of frozen vegetables, or as an alternative, a mixture of sawdust and water, and are to fill the freezer compartment to $75 \%$ of its full capacity. At least three of the frozen packages are to contain thermocouple probes, so that the measured temperature would represent the storage temperature of an item in the compartment.

The second difference between this test and that of the refrigerator-freezer is that the measurement period is much shorter. Since there is no defrost sequence to monitor, the test period must only characterize steady operation of the refrigerator. The test period for this refrigerator is to be a minimum of three hours, and is to encompass a whole number of compressor on/off cycles.

The last difference is that the target temperature for this test is warmer than that of the refrigerator-freezer. For this test, the target temperature is $-9.4^{\circ} \mathrm{C}\left(15^{\circ} \mathrm{F}\right)$ measured in the freezer compartment, or $7.2^{\circ} \mathrm{C}\left(45.0^{\circ} \mathrm{F}\right)$ measured in the refrigerator compartment, whichever gives the higher energy consumption value.

\section{2: International Organization for Standardization (ISO) Tests}

As was the case with the DOE tests, the manual defrost refrigerator falls under a different classification than the automatic defrost refrigerators. The three automatic defrost 
refrigerators were tested according to ISO 8561, Household frost-free refrigerating appliances - Refrigerators, refrigerator-freezers, frozen food storage cabinets and food freezers cooled by internal forced air circulation - Characteristics and test methods. The manual defrost refrigerator was tested in accordance with ISO 7371, Household refrigerating appliances - Refrigerators with or without low-temperature compartmentCharacteristics and test methods.

Under the ISO testing system, the freezer compartments of the refrigerators that are to be tested are sectioned and classified by a system that is indicative of the storage temperatures. Since none of the units tested in this study were manufactured for the European market, their freezer compartments were not classified by this system. The classification system separates the compartments into three classifications; $\mathrm{t}^{* * *}$ sections, $\mathrm{t}^{* *}$ sections, and $\mathrm{t}^{*}$ sections. The temperatures required to meet a certain classification are shown below in Table 4.1. For the purposes of this study, the freezer compartments were treated as though they were all $\mathrm{t}^{* *}$ compartments, as some of these units were not designed to easily attain temperatures that would qualify them as $t^{* * *}$ sections, and a consistent basis for comparison was needed.

Table 4.1 Required storage temperatures for ISO tests

\begin{tabular}{|c|c|}
\hline Compartment Type & Required Storage Temperature $\left({ }^{\circ} \mathbf{C}\right)$ \\
\hline $\mathrm{t}^{* * *}$ & $\leq-18$ \\
\hline $\mathrm{t}^{* *}$ & $\leq-12$ \\
\hline $\mathrm{t}^{*}$ & $\leq-6$ \\
\hline $\mathrm{t}_{\mathrm{m}}$ (Refrigerator Compartment) & $\leq 5$ \\
\hline $\mathrm{t}_{\mathrm{cm}}$ (Cellar Compartment) & $\leq 12$ \\
\hline
\end{tabular}

The ISO test requires that the refrigerator be tested in an environment of $25^{\circ} \mathrm{C}\left(77^{\circ} \mathrm{F}\right)$, with the relative humidity between $45 \%$ and $75 \%$. For all of the ISO tests performed in this study, the dew point was held at a constant $16^{\circ} \mathrm{C}\left(60.8^{\circ} \mathrm{F}\right)$, which corresponds to a humidity level of $58 \%$.

For the measurements of the energy consumption, the ISO test procedures require that the freezer compartment be loaded. The load packages that are required are composed of the following recipe, designed to mimic the thermal properties of lean beef:

Per 1,000 grams:

$230.0 \mathrm{~g}$ of oxyethylmethylcellulose

$764.2 \mathrm{~g}$ of water

$5.0 \mathrm{~g}$ of sodium chloride

$0.8 \mathrm{~g}$ of 6-chloro- $m$-cresol

This matter is formed into packages of the dimensions and mass specifications listed in Table 4.2: 
Table 4.2 Specifications for load packages required for ISO tests

\begin{tabular}{|c|c|}
\hline Dimensions (mm) & Mass (g) \\
\hline $25 \times 50 \times 100$ & 125 \\
\hline $50 \times 100 \times 100$ & 500 \\
\hline $50 \times 100 \times 200$ & 1000 \\
\hline
\end{tabular}

Some of the $500 \mathrm{~g}$ packages are to have thermocouple probes in the center of the packages. These are termed measurement packages, or commonly " $M$ " packages.

Finally, the ISO tests are a bit stricter than the DOE test procedure in that the reported temperature for a compartment is the maximum temperature seen from any thermocouple during the test. This maximum temperature must then satisfy the temperature requirements outlined in the procedures.

\section{$\underline{\text { ISO } 8561}$}

Packages are loaded into the freezer compartment in such a way that the compartment is essentially full, with the exception of minimum required spacing between stacks of packages. A number of " $M$ " packages are distributed throughout the freezer load packages. The refrigerator compartment is left empty, except for three "M" packages in the main refrigerator compartment and three " $\mathrm{M}$ " packages in the cellar compartments.

The test period is to be a minimum of $24 \mathrm{~h}$, and must be comprised of a whole number of operating cycles (i.e. from one point on a defrost sequence to the same point on another defrost sequence). If the defrost sequences are separated by more the $72 \mathrm{~h}$ of operation, then the test is terminated at $72 \mathrm{~h}$ and the defrost sequence is not taken into account.

The ISO 8561 test procedure does not instruct the settings of the thermostat(s), but rather provides a table of storage temperatures and states that the rated energy consumption ".... is that which is obtained when all the storage temperature conditions....are met simultaneously, and which gives the lowest energy consumption." The required temperatures are shown on the previous page in Table 4.1.

The portion of ISO 8561 that provides information for the energy consumption test does not state that a two part interpolated test, such as the DOE test procedure, may be used. However, a later section of the same procedure refers to the energy consumption test result being found through interpolation of two tests. Therefore, these tests were carried out in the same manner as the DOE test procedure.

$\underline{\text { ISO } 7371}$

The procedure outlined in ISO 7371 is similar to that outlined in ISO 8561 . However, there are three differences between these procedures. First, the fresh food compartment temperatures and any cellar compartment temperatures are not measured with "M" packages; rather they are measured with a thermocouple probe embedded in a small copper or brass cylinder. Secondly, the test period for this procedure is shorter than that 
of ISO 8561. Although the instructions are identical for the test period between ISO 8561 and ISO 7371 (a whole number of compressor cycles, and be at least $24 \mathrm{~h}$ ), less time is needed for ISO 7371 because there is no defrost cycle to wait for during the measurement period. And finally, this test procedure does explicitly state that a two part, interpolated test method is to be used. 


\section{5: Experimental Results}

\subsection{Side-By-Side Domestic Automatic Defrost Refrigerator-Freezer}

Table 5.1 shows the data obtained from the energy consumption measurements performed on the side-by-side, domestic, automatic defrost refrigerator-freezer.

Table 5.1 Test results for side-by-side refrigerator-freezer

\begin{tabular}{|c|c|c|c|c|}
\hline & \multicolumn{2}{|c|}{ Department of Energy Test } & \multicolumn{2}{|c|}{ ISO 8561} \\
\hline & $\begin{array}{l}\text { Median } \\
\text { Thermostat } \\
\text { Setting }\end{array}$ & $\begin{array}{c}\text { Warmest } \\
\text { Thermostat } \\
\text { Setting }\end{array}$ & $\begin{array}{l}\text { Median } \\
\text { Thermostat } \\
\text { Setting }\end{array}$ & $\begin{array}{c}\text { Warmest } \\
\text { Thermostat } \\
\text { Setting }\end{array}$ \\
\hline $\begin{array}{l}\text { Measurement } \\
\text { period }\end{array}$ & $\begin{array}{c}117595 \mathrm{~s} \\
(32: 39: 55)\end{array}$ & $\begin{array}{c}156551 \mathrm{~s} \\
(43: 29: 11)\end{array}$ & $\begin{array}{c}163080 \mathrm{~s} \\
(45: 18: 00)\end{array}$ & $\begin{array}{c}183000 \mathrm{~s} \\
(50: 50: 00)\end{array}$ \\
\hline $\begin{array}{l}\text { Average Power } \\
\text { during Test }\end{array}$ & $\begin{array}{c}118.55 \mathrm{~W} \\
\left(2.85 \frac{\mathrm{kW} \cdot \mathrm{h}}{\mathrm{d}}\right)\end{array}$ & $\begin{array}{c}96.59 \mathrm{~W} \\
\left(2.32 \frac{\mathrm{kW} \cdot \mathrm{h}}{\mathrm{d}}\right)\end{array}$ & $\begin{array}{c}84.55 \mathrm{~W} \\
\left(2.03 \frac{\mathrm{kW} \cdot \mathrm{h}}{\mathrm{d}}\right) \\
\end{array}$ & $\begin{array}{c}78.55 \mathrm{~W} \\
\left(1.89 \frac{\mathrm{kW} \cdot \mathrm{h}}{\mathrm{d}}\right) \\
\end{array}$ \\
\hline $\begin{array}{l}\text { Freezer } \\
\text { Temperature }\end{array}$ & $\begin{array}{c}-18.00^{\circ} \mathrm{C} \\
\left(-0.398^{\circ} \mathrm{F}\right) \\
\end{array}$ & $\begin{array}{c}-12.99^{\circ} \mathrm{C} \\
\left(8.625^{\circ} \mathrm{F}\right) \\
\end{array}$ & $\begin{array}{c}-12.99^{\circ} \mathrm{C} \\
\left(8.62^{\circ} \mathrm{F}\right) \\
\end{array}$ & $\begin{array}{r}-11.06^{\circ} \mathrm{C} \\
\left(12.09^{\circ} \mathrm{F}\right) \\
\end{array}$ \\
\hline $\begin{array}{l}\text { Ambient } \\
\text { Temperature }\end{array}$ & $\begin{array}{c}32.38^{\circ} \mathrm{C} \\
\left(90.29^{\circ} \mathrm{F}\right)\end{array}$ & $\begin{array}{c}32.32^{\circ} \mathrm{C} \\
\left(90.17^{\circ} \mathrm{F}\right)\end{array}$ & $\begin{array}{c}24.89^{\circ} \mathrm{C} \\
\left(76.80^{\circ} \mathrm{F}\right) \\
\end{array}$ & $\begin{array}{c}24.90^{\circ} \mathrm{C} \\
\left(76.82^{\circ} \mathrm{F}\right)\end{array}$ \\
\hline Final Result & $\begin{array}{r}2.530 \\
\text { interpolated } \\
\end{array}$ & $\begin{array}{l}\frac{W \cdot h}{d} \\
-15^{\circ} \mathrm{C}\left(5^{\circ} \mathrm{F}\right)\end{array}$ & $\begin{array}{r}1.95 \\
\text { interpolated }\end{array}$ & $\begin{array}{l}\frac{W \cdot h}{d} \\
12^{\circ} \mathrm{C}\left(10.4^{\circ} \mathrm{F}\right)\end{array}$ \\
\hline
\end{tabular}

As expected, the energy consumption of this unit as tested by the DOE test procedure was higher than the value obtained using ISO 8561. This is mainly due to the fact that the DOE test procedure requires a larger temperature difference between the coldest cabinet and the ambient. What is interesting about these results is the relative increase in the amount of energy consumption. The energy consumption measured by the DOE test procedure was $29.4 \%$ greater than that measured by the ISO test procedure. For the test data shown in Table 5.1, the temperature difference between the coldest compartment and the ambient temperature was $28.8 \%$ greater for the DOE test procedure.

Using the algorithm outlined by Bansal and Krüger, these operating conditions would result in COP and $\triangle T$ of 4.09 and $47.35^{\circ} \mathrm{C}$ for the DOE test procedure; and 4.99 and $36.89^{\circ} \mathrm{C}$ for the ISO test procedure. The correlation derived in their study results in a calculated DOE result of $2.70 \frac{\mathrm{kW} \cdot \mathrm{h}}{\mathrm{d}}$, based on the ISO test measurements, which is $6.8 \%$ above the measured value. The values for $\Delta T_{\text {cond }}$ and $\Delta T_{\text {evap }}$ were fixed at $7{ }^{\circ} \mathrm{C}$ for this calculation, however this unit uses forced convection for the evaporator and condenser, which would decrease these temperature differences. Using smaller temperature differences would, however, result in a larger difference between the calculated value and the measured value. 


\subsection{Top Mounted Domestic Automatic Defrost Refrigerator-Freezer}

Table 5.2 shows the data obtained from the energy consumption measurements performed on the top mounted, domestic, automatic defrost refrigerator-freezer.

Table 5.2 Test results for top mounted refrigerator-freezer

\begin{tabular}{|c|c|c|c|c|}
\hline & \multicolumn{2}{|c|}{ Department of Energy Test } & \multicolumn{2}{|c|}{ ISO 8561} \\
\hline & $\begin{array}{l}\text { Median } \\
\text { Thermostat } \\
\text { Setting }\end{array}$ & $\begin{array}{c}\text { Warmest } \\
\text { Thermostat } \\
\text { Setting }\end{array}$ & $\begin{array}{l}\text { Median } \\
\text { Thermostat } \\
\text { Setting }\end{array}$ & $\begin{array}{c}\text { Warmest } \\
\text { Thermostat } \\
\text { Setting }\end{array}$ \\
\hline $\begin{array}{l}\text { Measurement } \\
\text { period }\end{array}$ & $\begin{array}{c}2 \text { part } \\
\mathrm{CT}=143.7 \mathrm{~h}\end{array}$ & $\begin{array}{c}2 \text { part } \\
\mathrm{CT}=181.6 \mathrm{~h}\end{array}$ & $\begin{array}{c}260586 \mathrm{~s} \\
(72: 23: 06)\end{array}$ & $\begin{array}{c}260430 \mathrm{~s} \\
(72: 20: 30)\end{array}$ \\
\hline $\begin{array}{l}\text { Average Power } \\
\text { during Test }\end{array}$ & $\begin{array}{c}66.66 \mathrm{~W} \\
\left(1.60 \frac{\mathrm{kW} \cdot \mathrm{h}}{\mathrm{d}}\right)\end{array}$ & $\begin{array}{c}56.04 \mathrm{~W} \\
\left(1.34 \frac{\mathrm{kW} \cdot \mathrm{h}}{\mathrm{d}}\right)\end{array}$ & $\begin{array}{c}44.42 \mathrm{~W} \\
\left(1.07 \frac{\mathrm{kW} \cdot \mathrm{h}}{\mathrm{d}}\right)\end{array}$ & $\begin{array}{c}44.27 \mathrm{~W} \\
\left(1.06 \frac{\mathrm{kW} \cdot \mathrm{h}}{\mathrm{d}}\right)\end{array}$ \\
\hline $\begin{array}{l}\text { Freezer } \\
\text { Temperature }\end{array}$ & $\begin{array}{l}-21.02^{\circ} \mathrm{C} \\
\left(-5.84^{\circ} \mathrm{F}\right)\end{array}$ & $\begin{array}{l}-17.87^{\circ} \mathrm{C} \\
\left(-0.16^{\circ} \mathrm{F}\right) \\
\end{array}$ & $\begin{array}{c}-16.86^{\circ} \mathrm{C} \\
\left(1.65^{\circ} \mathrm{F}\right)\end{array}$ & $\begin{array}{l}-16.54^{\circ} \mathrm{C} \\
\left(2.23^{\circ} \mathrm{F}\right) \\
\end{array}$ \\
\hline $\begin{array}{l}\text { Ambient } \\
\text { Temperature }\end{array}$ & $\begin{array}{c}32.24^{\circ} \mathrm{C} \\
\left(90.03^{\circ} \mathrm{F}\right) \\
\end{array}$ & $\begin{array}{c}32.33^{\circ} \mathrm{C} \\
\left(90.19^{\circ} \mathrm{F}\right) \\
\end{array}$ & $\begin{array}{c}25.14^{\circ} \mathrm{C} \\
\left(77.25^{\circ} \mathrm{F}\right)\end{array}$ & $\begin{array}{c}25.11^{\circ} \mathrm{C} \\
\left(77.20^{\circ} \mathrm{F}\right)\end{array}$ \\
\hline Final Result & $\begin{array}{r}1.34 \\
\text { minimum at }\end{array}$ & $\begin{array}{l}\frac{V \cdot h}{d} \\
9^{\circ} \mathrm{C}\left(-0.2^{\circ} \mathrm{F}\right)\end{array}$ & $\begin{array}{r}1.06 \\
\text { minimum at }\end{array}$ & $\begin{array}{l}\frac{W \cdot h}{d} \\
.5^{\circ} \mathrm{C}\left(2.3^{\circ} \mathrm{F}\right)\end{array}$ \\
\hline
\end{tabular}

The U. S. test procedure resulted in an energy consumption value that was $26.6 \%$ higher than the ISO test, while operating across a temperature difference that is $20.6 \%$ larger. This is fairly similar to the results of the side-by-side refrigerator; however, there are a few other factors that need to be taken into consideration when examining the data for this unit.

First and foremost, this particular refrigerator was always too cold. The final result could not be interpolated to the target temperature for either test because, even at the warmest thermostat setting, the freezer compartment temperature was colder than the test target temperatures of $-15^{\circ} \mathrm{C}\left(5^{\circ} \mathrm{F}\right)$ for the DOE procedure and $-12^{\circ} \mathrm{C}\left(10.4^{\circ} \mathrm{F}\right)$ for the ISO procedure. According to the DOE and ISO 8561 procedures, if this occurs then the value obtained at the warmest setting and the corresponding temperatures are to be reported.

In addition, this unit displayed the "long-term automatic defrost" characteristics outlined in the DOE test procedure. The time between defrost sequences is denoted as CT for the DOE test results, and it is shown that this unit undergoes a defrost sequence approximately once per week. Therefore, the procedure that was used requires two separate measurements, one of the steady state performance and one of the defrost sequence, which draws approximately twice as much power as steady operation. These measurements are then combined to give a time weighted average of all amounts of energy used during operation. 
Conversely, for the ISO test procedure, since no defrost sequence occurred over the $72 \mathrm{~h}$ test period, the defrost sequence was not taken into account. By closer examination of the data from the DOE test, it is seen that accounting for the defrost energy adds only $0.6 \%$ to the energy consumption for this unit. This is actually a bit low for the addition of the defrost power, but that is due to very large time between defrost cycles. In general, excluding the defrost power used on units that cycle less than once every $72 \mathrm{~h}$ results in less than $2 \%$ savings in the energy consumption.

Comparing the results of this test to the study of Bansal and Krüger, these operating conditions would result in $\mathrm{COP}$ and $\triangle \mathrm{T}$ of 3.87 and $50.19^{\circ} \mathrm{C}$ for the DOE test procedure, and 4.89 and $41.62{ }^{\circ} \mathrm{C}$ for the ISO test procedure; assuming the same $\Delta T_{\text {cond }}$ and $\Delta T_{\text {evap }}$ as was used in their study. Their correlation agrees very well with the measured values for this test. The calculated DOE test result is $1.35 \frac{\mathrm{kW} \cdot \mathrm{h}}{\mathrm{d}}$, based on the ISO test measurements and the other parameters. This unit, however, uses forced convection to drive the heat transfer across its heat exchangers; therefore the values for $\Delta T_{\text {cond }}$ and $\Delta T_{\text {evap }}$ are a bit unrealistic for this refrigerator. Lowering the values of these parameters would again add disagreement between the calculated values and the measured values.

\subsection{Top Mounted Automatic Defrost Refrigerator with Energy Saving Technologies}

The data from the energy consumption tests of the automatic defrost refrigerator with unique energy saving features is shown below in Table 5.3. 
Table 5.3 Test results for top mounted refrigerator with energy saving technologies

\begin{tabular}{|c|c|c|c|c|}
\hline & \multicolumn{2}{|c|}{ Department of Energy Test } & \multicolumn{2}{|c|}{ ISO 8561} \\
\hline & $\begin{array}{l}\text { Median } \\
\text { Thermostat } \\
\text { Setting }\end{array}$ & $\begin{array}{c}\text { Warmest } \\
\text { Thermostat } \\
\text { Setting }\end{array}$ & $\begin{array}{l}\text { Median } \\
\text { Thermostat } \\
\text { Setting }\end{array}$ & $\begin{array}{c}\text { Warmest } \\
\text { Thermostat } \\
\text { Setting }\end{array}$ \\
\hline $\begin{array}{l}\text { Measurement } \\
\text { period }\end{array}$ & $\begin{array}{c}2 \text { part } \\
\mathrm{CT}=67.2 \mathrm{hr}\end{array}$ & $\begin{array}{c}2 \text { part } \\
\mathrm{CT}=75.1 \mathrm{hr}\end{array}$ & $\begin{array}{c}259568 \mathrm{~s} \\
(72: 06: 08)\end{array}$ & $\begin{array}{c}261088 \mathrm{~s} \\
(72: 31: 28)\end{array}$ \\
\hline $\begin{array}{l}\text { Average Power } \\
\text { during Test }\end{array}$ & $\begin{array}{c}63.50 \mathrm{~W} \\
\left(1.55 \frac{\mathrm{kW} \cdot \mathrm{h}}{\mathrm{d}}\right)\end{array}$ & $\begin{array}{c}54.24 \mathrm{~W} \\
\left(1.32 \frac{\mathrm{kW} \cdot \mathrm{h}}{\mathrm{d}}\right)\end{array}$ & $\begin{array}{c}50.52 \mathrm{~W} \\
\left(1.21 \frac{\mathrm{kW} \cdot \mathrm{h}}{\mathrm{d}}\right)\end{array}$ & $\begin{array}{c}42.39 \mathrm{~W} \\
\left(1.02 \frac{\mathrm{kW} \cdot \mathrm{h}}{\mathrm{d}}\right)\end{array}$ \\
\hline $\begin{array}{l}\text { Freezer } \\
\text { Temperature }\end{array}$ & $\begin{array}{r}-16.93^{\circ} \mathrm{C} \\
\left(1.52^{\circ} \mathrm{F}\right) \\
\end{array}$ & $\begin{array}{c}-12.80^{\circ} \mathrm{C} \\
\left(8.96^{\circ} \mathrm{F}\right) \\
\end{array}$ & $\begin{array}{r}-13.02^{\circ} \mathrm{C} \\
\left(8.57^{\circ} \mathrm{F}\right) \\
\end{array}$ & $\begin{array}{c}-9.84^{\circ} \mathrm{C} \\
\left(14.28^{\circ} \mathrm{F}\right)\end{array}$ \\
\hline $\begin{array}{l}\text { Ambient } \\
\text { Temperature }\end{array}$ & $\begin{array}{r}32.16^{\circ} \mathrm{C} \\
\left(89.89^{\circ} \mathrm{F}\right) \\
\end{array}$ & $\begin{array}{r}32.30^{\circ} \mathrm{C} \\
\left(90.14^{\circ} \mathrm{F}\right) \\
\end{array}$ & $\begin{array}{l}25.19^{\circ} \mathrm{C} \\
\left(77.34^{\circ} \mathrm{F}\right) \\
\end{array}$ & $\begin{array}{c}25.11^{\circ} \mathrm{C} \\
\left(77.20^{\circ} \mathrm{F}\right)\end{array}$ \\
\hline Final Result & 1.44 & $\begin{array}{l}\frac{W \cdot h}{d} \\
-15^{\circ} \mathrm{C}\left(5^{\circ} \mathrm{F}\right)\end{array}$ & $\begin{array}{r}1.15 \\
\text { interpolated }\end{array}$ & $\frac{\mathrm{W} \cdot \mathrm{h}}{\mathrm{d}}$ \\
\hline
\end{tabular}

The energy consumption of this unit, as tested by the DOE test procedure resulted in a value that was $25.0 \%$ higher than that under the ISO test, while operating across a temperature difference that was $27.1 \%$ larger. This is in line with the results of the other refrigerators tested in this study. As was the case with the top mounted domestic unit discussed in section 5.2, the defrost portion was not factored into the ISO test calculations. Including the energy for the DOE test procedure added $1.4 \%$ to the energy consumption measurement.

Comparing these results to Bansal and Krüger, the COP and $\Delta T$ are 4.10 and $47.23{ }^{\circ} \mathrm{C}$ for the DOE test procedure; and 4.97 and $37.15^{\circ} \mathrm{C}$ for the ISO test procedure, which would result in a calculated energy consumption of $1.57 \frac{\mathrm{kW} \cdot \mathrm{h}}{\mathrm{d}}$ for the DOE test procedure. This unit performed quite better, however, under the DOE test procedure.

This particular unit used forced air over the evaporator and natural convection over the condenser. Therefore the value for $\Delta T_{\text {cond }}$ may have been fairly suited, but the value for $\Delta T_{\text {evap }}$, would be too large, and lowering this parameter would add more disagreement between the correlation and the test data.

This unit used $25.0 \%$ more energy under the DOE test procedure than under the ISO test procedure, which is the smallest increase seen for any of the refrigerator-freezers tested in this study. This unit is also the only one tested which showed an increase in energy consumption that is relatively smaller than the increase in the temperature difference prescribed by the two test procedures. This is attributed to the variable speed fans because the other special feature of this unit (the intelligent defrost sequence) would benefit the results of both the ISO and DOE tests. 
This unit was able to meet the additional capacity required to operate in the more difficult DOE test environment, without realizing as much of an increase in energy usage as the other units. This is because the variable speed fans add an additional degree of freedom for use by the controlling electronics to optimize the capacity of the cooling cycle. This test demonstrated that this unit can respond to changes in the operating conditions without as harsh of an increase in energy consumption through fine tuning its operational parameters, thereby making it less sensitive to the conditions than other units.

\subsection{Manual Defrost Refrigerator}

As mentioned earlier, the test procedures for the manual defrost refrigerator are different than for the automatic defrost models. For this unit, the "basic refrigerator" portions of the DOE test procedure were followed, and the corresponding ISO test procedure for this unit is ISO 7371. For the DOE test, the interpolated target temperature is to be either $7.2{ }^{\circ} \mathrm{C}\left(45^{\circ} \mathrm{F}\right)$ in the refrigerator or $-9.4^{\circ} \mathrm{C}\left(15^{\circ} \mathrm{F}\right)$ in the freezer, whichever yields the greater value for the energy consumption. For the ISO test, the lowest energy consumption that results in meeting all temperature requirements outlined in Table 4.2 is to be reported.

The results from the tests are shown in Table 5.4. For the DOE test, the temperature requirement for the refrigerator compartment was the tougher requirement to meet. Therefore, the energy consumption was based on the refrigerator compartment temperature. The ISO test results are a bit more difficult to analyze, due to the fact that the compartments of this unit are not labeled according to the ISO star classification system. If the freezer compartment were considered to be a $t^{* *}$ compartment (as was used as the basis for the three automatic defrost units), then the energy consumption value would be interpolated to satisfy this compartments' requirement. If, however, the freezer were to be considered to be a $t^{*}$ compartment, then the refrigerator compartment temperature would be the more difficult requirement to meet. Since the results for the ISO tests show such a large difference in energy consumption, the best way to compare these results to those of the DOE tests is to compare the DOE test with freezer interpolation to the ISO $\mathrm{t}^{*}{ }^{*}$ test and compare the DOE test with refrigerator interpolation to the ISO $\mathrm{t}^{*}$ test. 
Table 5.4 Test results for manual defrost refrigerator

\begin{tabular}{|c|c|c|c|c|}
\hline & \multicolumn{2}{|c|}{ Department of Energy Test } & \multicolumn{2}{|c|}{ ISO 8561} \\
\hline & $\begin{array}{l}\text { Median } \\
\text { Thermostat } \\
\text { Setting }\end{array}$ & $\begin{array}{c}\text { Warmest } \\
\text { Thermostat } \\
\text { Setting }\end{array}$ & $\begin{array}{c}\text { Median } \\
\text { Thermostat } \\
\text { Setting }\end{array}$ & $\begin{array}{c}\text { Coldest } \\
\text { Thermostat } \\
\text { Setting }\end{array}$ \\
\hline $\begin{array}{l}\text { Measurement } \\
\text { period }\end{array}$ & $\begin{array}{c}13769 \mathrm{~s} \\
(3: 49: 29) \\
\end{array}$ & $\begin{array}{c}12010 \mathrm{~s} \\
(3: 20: 10)\end{array}$ & $\begin{array}{c}87499 \mathrm{~s} \\
(24: 18: 19)\end{array}$ & $\begin{array}{c}90174 \mathrm{~s} \\
(25: 02: 54)\end{array}$ \\
\hline $\begin{array}{l}\text { Average Power } \\
\text { during Test }\end{array}$ & $\left(1.86 \frac{\mathrm{kW} \cdot \mathrm{h}}{\mathrm{d}}\right)$ & $\begin{array}{c}52.48 \mathrm{~W} \\
\left(1.26 \frac{\mathrm{kW} \cdot \mathrm{h}}{\mathrm{d}}\right) \\
\end{array}$ & $\begin{array}{r}53.35 \mathrm{~W} \\
\left(1.28 \frac{\mathrm{kW} \cdot \mathrm{h}}{\mathrm{d}}\right) \\
\end{array}$ & $\begin{array}{c}75.62 \mathrm{~W} \\
\left(1.81 \frac{\mathrm{kW} \cdot \mathrm{h}}{\mathrm{d}}\right)\end{array}$ \\
\hline $\begin{array}{l}\text { Refrigerator } \\
\text { Temperature }\end{array}$ & $\begin{array}{c}6.20^{\circ} \mathrm{C} \\
\left(43.16^{\circ} \mathrm{F}\right) \\
\end{array}$ & $\begin{array}{c}12.61^{\circ} \mathrm{C} \\
\left(54.69^{\circ} \mathrm{F}\right) \\
\end{array}$ & $\begin{array}{c}5.36^{\circ} \mathrm{C} \\
\left(41.65^{\circ} \mathrm{F}\right)\end{array}$ & $\begin{array}{c}-0.01^{\circ} \mathrm{C} \\
\left(31.99^{\circ} \mathrm{F}\right)\end{array}$ \\
\hline $\begin{array}{l}\text { Freezer } \\
\text { Temperature }\end{array}$ & $\begin{array}{l}-13.26^{\circ} \mathrm{C} \\
\left(8.14^{\circ} \mathrm{F}\right) \\
\end{array}$ & $\begin{array}{c}-3.88^{\circ} \mathrm{C} \\
\left(25.02^{\circ} \mathrm{F}\right) \\
\end{array}$ & $\begin{array}{c}-6.46^{\circ} \mathrm{C} \\
\left(20.37^{\circ} \mathrm{F}\right) \\
\end{array}$ & $\begin{array}{l}-13.18^{\circ} \mathrm{C} \\
\left(8.28^{\circ} \mathrm{F}\right) \\
\end{array}$ \\
\hline $\begin{array}{l}\text { Ambient } \\
\text { Temperature }\end{array}$ & $\begin{array}{c}32.11^{\circ} \mathrm{C} \\
\left(89.79^{\circ} \mathrm{F}\right) \\
\end{array}$ & $\begin{array}{c}32.12^{\circ} \mathrm{C} \\
\left(89.82^{\circ} \mathrm{F}\right)\end{array}$ & $\begin{array}{c}24.84^{\circ} \mathrm{C} \\
\left(76.71^{\circ} \mathrm{F}\right)\end{array}$ & $\begin{array}{c}24.94^{\circ} \mathrm{C} \\
\left(76.89^{\circ} \mathrm{F}\right)\end{array}$ \\
\hline \multirow[t]{3}{*}{ Results } & \multicolumn{2}{|c|}{$\begin{array}{l}1.61 \frac{\mathrm{kW} \cdot \mathrm{h}}{\mathrm{d}} \\
\text { interpolated at }-9.4^{\circ} \mathrm{C}\left(15^{\circ} \mathrm{F}\right) \\
\text { in freezer compartment }\end{array}$} & \multicolumn{2}{|c|}{$\begin{array}{l}\text { interpolated at }-12^{\circ} \mathrm{C}\left(10.4^{\circ} \mathrm{F}\right) \\
\text { in freezer compartment }\left(\mathrm{t}^{* *}\right)\end{array}$} \\
\hline & & & \multicolumn{2}{|c|}{$\begin{array}{c}1.24 \frac{\mathrm{kW} \cdot \mathrm{h}}{\mathrm{d}} \\
\text { interpolated at }-6^{\circ} \mathrm{C}\left(21.2^{\circ} \mathrm{F}\right) \\
\text { in freezer compartment }\left(\mathrm{t}^{*}\right)\end{array}$} \\
\hline & \multicolumn{2}{|c|}{$\begin{array}{l}1.76 \frac{\mathrm{kW} \cdot \mathrm{h}}{\mathrm{d}} \\
\text { interpolated at } 7.2^{\circ} \mathrm{C}\left(45^{\circ} \mathrm{F}\right) \\
\text { in refrigerator compartment }\end{array}$} & \multicolumn{2}{|c|}{$\begin{array}{l}1.32 \frac{\mathrm{kW} \cdot \mathrm{h}}{\mathrm{d}} \\
\text { interpolated at } 5^{\circ} \mathrm{C}\left(41.0^{\circ} \mathrm{F}\right) \\
\text { in refrigerator compartment }\end{array}$} \\
\hline
\end{tabular}

Upon examining the data from the ISO tests, it is seen that if the freezer compartment is considered a t** compartment, then freezer compartment temperatures are used as the basis for interpolation, and the measurements return an energy consumption result that seems a bit too large. In fact, the result is an energy consumption that is greater than that found during the DOE test, while operating across a smaller temperature difference.

Considering that the coldest temperatures attained at the lowest thermostat for this unit are close to the $t^{* *}$ target temperature, it is a reasonable assumption that this unit was not designed for operation in this temperature range and that this unit is near its limit of performance.

On the other hand, if this freezer compartment were considered to be a t* compartment for the ISO test, then the refrigerator compartment temperature would be the more restrictive temperature. If the results of this ISO test calculation and the DOE test are compared, then these results show an increase in energy consumption of $33.3 \%$ while 
operating across a temperature difference that is $25.2 \%$ greater, which is similar to the results of the other three units tested in this study.

Comparing the results of this test to the study of Bansal and Krüger, the COP's and $\Delta T$ 's are 5.66 and $24.91{ }^{\circ} \mathrm{C}$ for the DOE test procedure; and 6.28 and $19.89^{\circ} \mathrm{C}$ for the ISO test procedure. The COP terms are found using a $15^{\circ} \mathrm{C}$ temperature difference for the evaporator and a $7^{\circ} \mathrm{C}$ temperature difference for the condenser. This results in a calculated energy consumption of $1.64 \frac{\mathrm{kW} \cdot \mathrm{h}}{\mathrm{d}}$ for the DOE test procedure, which is $6.8 \%$ below the measured value. Lowering the temperature difference across the condenser for this unit to account for the forced convection would also result in a greater difference between the data and the correlation.

\subsection{Overall Results}

A summary of the test results obtained during these measurements is depicted in Figure 5.1. In all cases, the results of the tests showed that the refrigerators used considerably more energy under the DOE tests than under the ISO tests. For the three automatic defrost refrigerator-freezers, the DOE test measured the energy consumption to be $25.0 \%$ to $29.4 \%$ higher than the ISO test. The manual defrost refrigerator used $33.3 \%$ more energy under the DOE test conditions than under the ISO test.

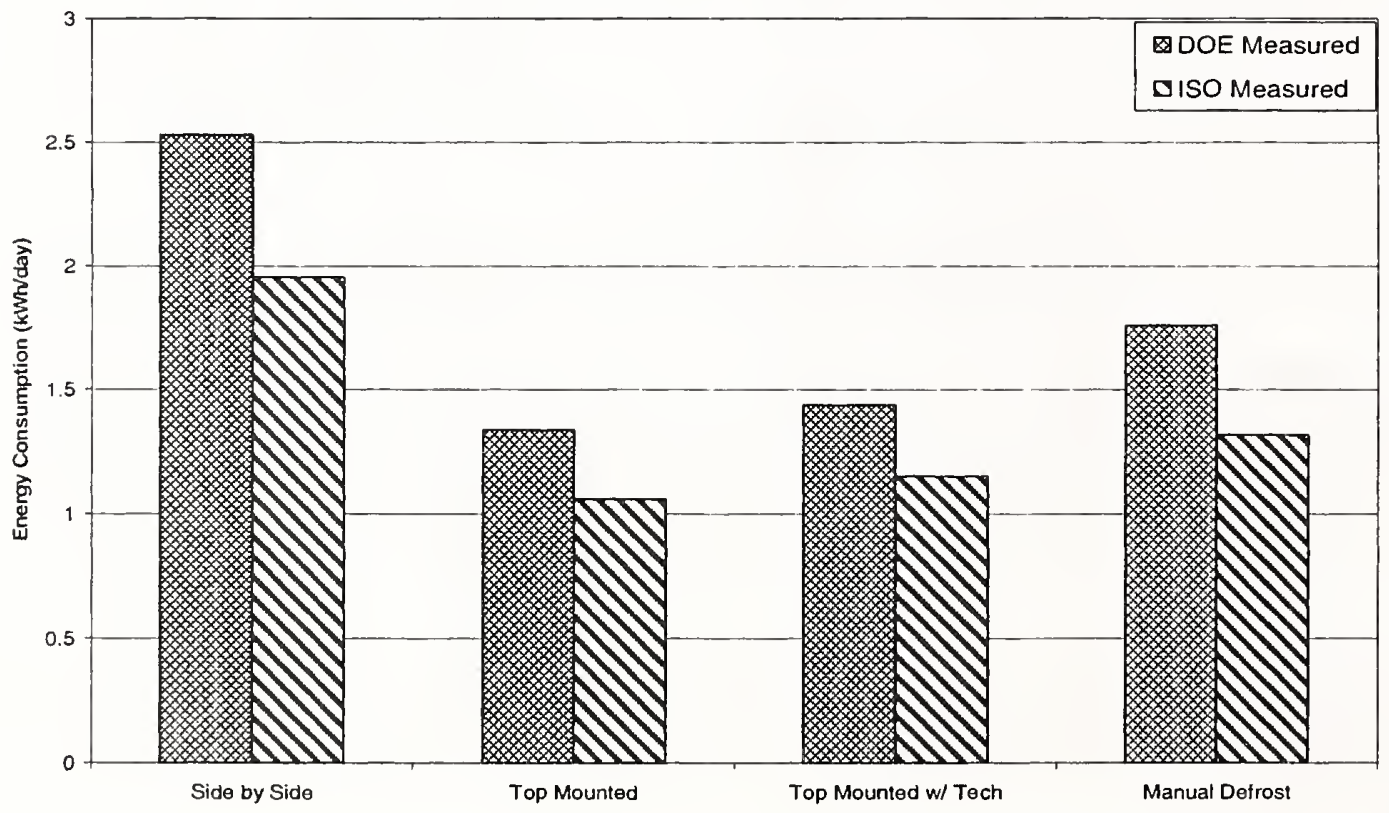

Figure 5.1 Summary of all test data measured during this study 
Figure 5.2 shows the measured energy consumption test results for the DOE tests on the three automatic defrost units. Also shown on this figure are the predicted values of the energy consumption based on results of the ISO tests and the correlation developed at the University of Auckland.

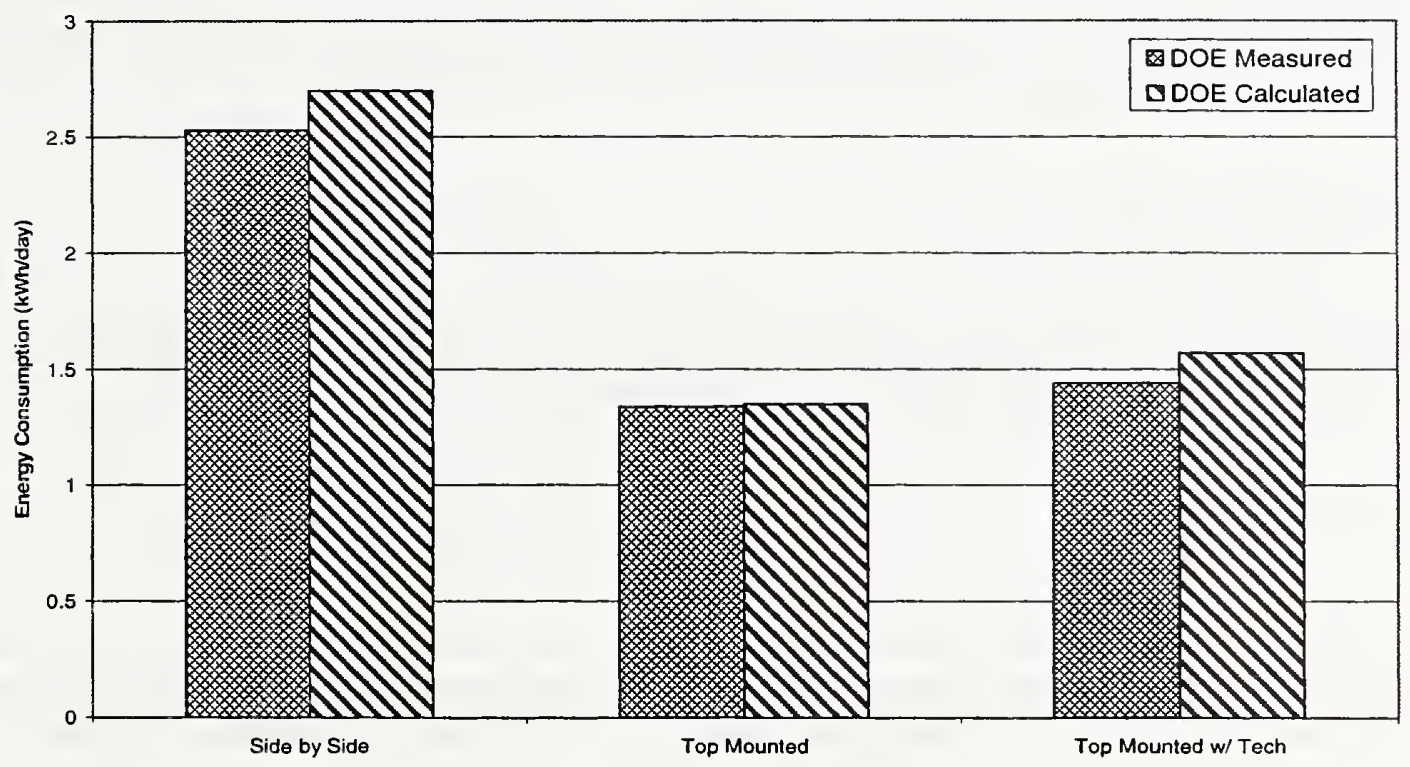

Figure 5.2 Comparison of test results to correlation for automatic defrost units

For all three of the automatic defrost refrigerator-freezers, the predictions were $0.7 \%$ to $9 \%$ higher than the measured values. Since the correlation consistently predicted a value that was higher than the measured value, it seems that this correlation can be modified to better predict the performance of automatic defrost refrigerator-freezers.

The parameters that are used in the Bansal-Krüger correlation are fundamentally important to the refrigeration cycle; however the dependence of each parameter may not be accurate due to the empirical method of determination. Although there is not enough data to develop a useful correction to the Bansal-Krüger correlation, it may be helpful to address the physics of this situation. For each unit, the COP is defined as the amount of cooling divided by the compressor work.

$\mathrm{COP}=\frac{Q_{\text {evap }}}{W}$

This, in turn, means that the work of the compressor can be expressed as the ratio of the cooling power to the COP.

$W=\frac{Q_{\text {evap }}}{\mathrm{COP}}$ 
The amount of cooling power that is needed to maintain a certain temperature within the cabinet is the product of the overall heat transfer coefficient of the cabinet and the temperature difference between the ambient temperature and the internal cabinet temperature.

\section{$Q_{\text {evap }}=U A \Delta T$}

Therefore, a ratio of the compressor work under one test procedure to that under another procedure could then be expressed as:

$\frac{W_{A}}{W_{B}}=\frac{\operatorname{COP}_{B}}{\operatorname{COP}_{A}} \frac{U A_{A}}{U A_{B}} \frac{\Delta T_{A}}{\Delta T_{B}}$

Since the overall heat transfer coefficient of the cabinet will not change significantly between two sets of operating conditions, this can be reduced to:

$\frac{W_{A}}{W_{B}}=\frac{\operatorname{COP}_{B}}{\operatorname{COP}_{A}} \frac{\Delta T_{A}}{\Delta T_{B}}$

Although this seems rather straight forward in theory, this is not necessarily accurate in practice. This does, however, suggest that the dependence of a working correlation on the temperature difference parameter should be stronger than the square root relationship used in the Bansal-Krüger correlation.

Furthermore, the calculated values for the COP under each test were estimated using a $7{ }^{\circ} \mathrm{C}$ temperature difference between the evaporating temperature and the refrigerator's internal temperature. $7{ }^{\circ} \mathrm{C}$ was also used as the temperature difference between the ambient temperature and the condensing temperature. This value is too large for these units. Unfortunately, the actual $\Delta T_{\text {evap }}$ and $\Delta T_{\text {cond }}$ were not measured during these tests, nor would they be easily measured as the evaporator is generally not accessible to the user. Therefore, it may be difficult to introduce this parameter into a working correlation at all.

With data from only three automatic defrost refrigerator-freezers, it is premature to develop a useful correction to the Bansal-Krüger correlation. Therefore, more test data should be taken on a variety of units in order to develop a better understanding of the influences involved with these two test procedures. 


\section{6: Summary}

The purpose of this experimental investigation was to examine the differences between energy consumption ratings obtained from tests according to the United States Department of Energy test procedure and their analogous ISO test rating procedures. Four refrigerators were tested by each appropriate standard in this study.

During the tests, the results showed that the DOE test procedure consistently produced a larger value for the energy consumption. This was in line with the expectations due to the fact that the DOE test procedure requires that the units operate in a warmer environment during the test.

Overall, the correlation developed by Bansal and Krüger agreed with the data from this study to within $10 \%$. However, their correlation was developed empirically from data obtained from refrigerators which operated using a different refrigerant; and the predictions seemed to be consistently higher than the measured data for the refrigeratorfreezers. This suggests that there may be other factors which can be included into this correlation to broaden its scope; which could then be used as a step towards an international test procedure. However, it would be necessary to examine more units to accurately compile a working correlation.

The relative ranking of the units tested were identical under both standards. This implies that both the DOE and ISO test procedures are adequate tools that can be used to accomplish the same task. Some of the steps of the procedures differ in ways that complicate the testing; such as the freezer loading for the ISO tests, which greatly increases the amount of time required to setup the tests and to achieve steady state test conditions. Other procedural steps that vary between the standards are somewhat arbitrary; such as the measurement period, which in all cases is averaged over a whole number of periodic events. In general, however, the test procedures are similar in nature. 


\section{7: References}

1. Association of Home Appliance Manufacturers American National Standard, Household Refrigerators/Household Freezers, ANSI/AHAM HRF-1-1988, Chicago (1988).

2. Bansal P. K. and Krüger $\mathbf{R}$. Test standards for household refrigerators and freezers I: preliminary comparisons, Int. J Refrigeration, 18 (1), 4-20 (1995).

3. International Organization for Standardization International Standard ISO 5155, Household refrigerating appliances - Frozen food storage cabinets and food freezers-Characteristics and test methods, 1995.

4. International Organization for Standardization International Standard ISO 7371, Household frost-free refrigerating appliances - Refrigerators with or without low-temperature compartment - Characteristics and test methods, 1995.

5. International Organization for Standardization International Standard ISO 8187, Household refrigerating appliances - Refrigerator-freezers Characteristics and test methods, 1995.

6. International Organization for Standardization International Standard ISO 8561, Household frost-free refrigerating appliances - Refrigerators, refrigerator-freezers, frozen food storage cabinets and food freezers cooled by internal forced air circulation - Characteristics and test methods, 1995. 


\section{Appendix A: Test Information}

This appendix provides photographs and figures specific to the performance of each refrigerator for the energy consumption tests performed at NIST. All of the tabulated data is provided within the body of this report; these figures are representative of the raw data.

\section{A.1 Side-By-Side Domestic Automatic Defrost Refrigerator-Freezer DOE Tests}

Voltage input during test:

Median Setting: $114.7 \mathrm{~V}, 60 \mathrm{~Hz}$, voltage variance $0.65 \mathrm{~V}$

Warm Setting: $114.9 \mathrm{~V}, 60 \mathrm{~Hz}$, voltage variance $0.89 \mathrm{~V}$

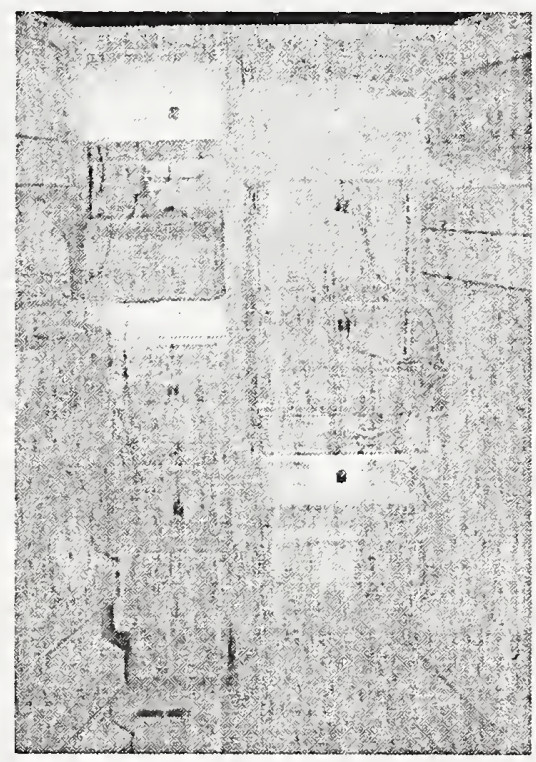

Figure A.1 Side-by-side domestic automatic defrost refrigerator-freezer Prepared for DOE tests 


\section{ISO Tests}

Voltage input during test:

First Setting: $114.9 \mathrm{~V}, 60 \mathrm{~Hz}$, voltage variance $0.49 \mathrm{~V}$

Second Setting: $114.9 \mathrm{~V}, 60 \mathrm{~Hz}$, voltage variance $0.32 \mathrm{~V}$

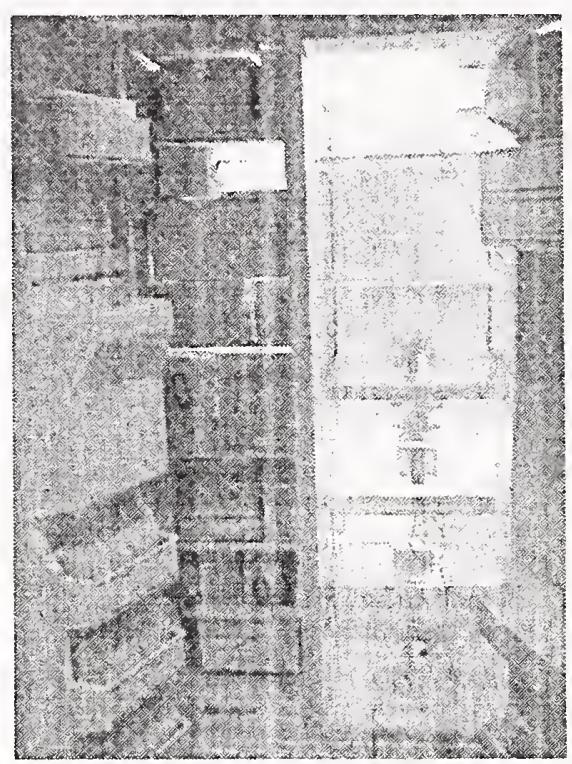

Figure A.2 Side-by-side domestic automatic defrost refrigerator-freezer Prepared for ISO tests

Defrost Cycle Power for Side by Side Refrigerator-Freezer

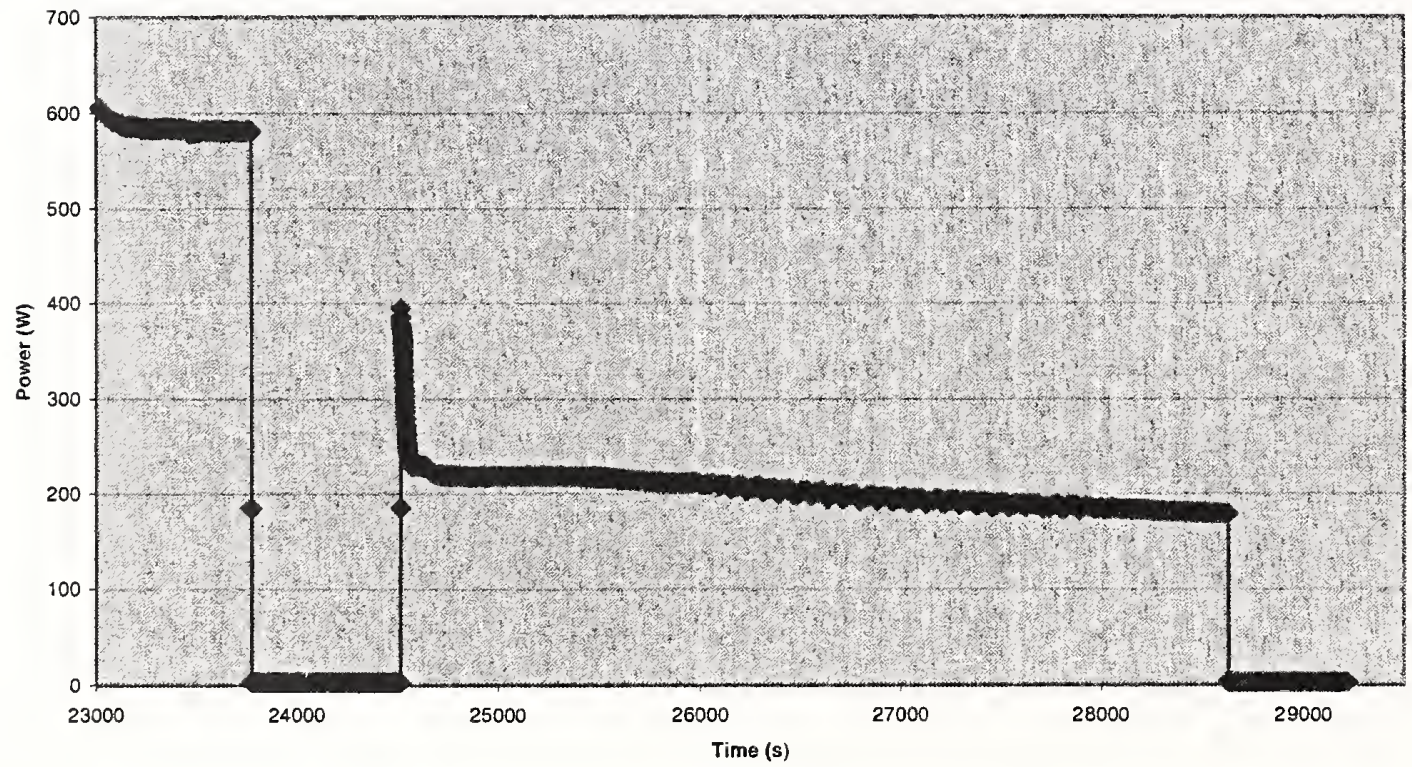

Figure A.3 Side-by-side domestic automatic defrost refrigerator-freezer Plot of typical energy usage during defrost sequence 


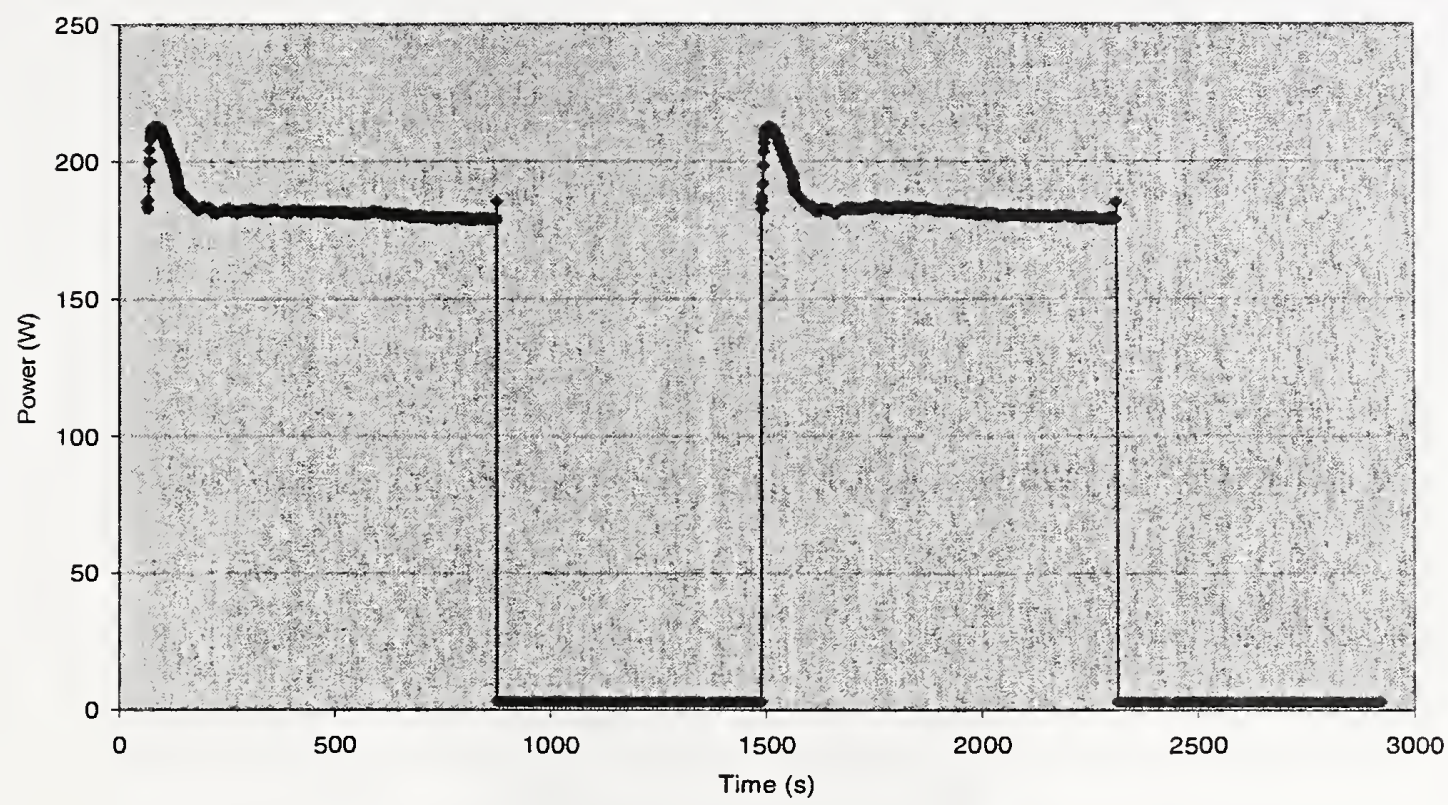

Figure A.4 Side-by-side domestic automatic defrost refrigerator-freezer Plot of typical energy usage during steady state operation

\section{A. 2 Top Mount Domestic Automatic Defrost Refrigerator-Freezer}

\section{DOE Tests}

Voltage input during test:

Median Setting: $115.2 \mathrm{~V}, 60 \mathrm{~Hz}$, voltage variance $0.13 \mathrm{~V}$

Warm Setting: $115.3 \mathrm{~V}, 60 \mathrm{~Hz}$, voltage variance $0.14 \mathrm{~V}$

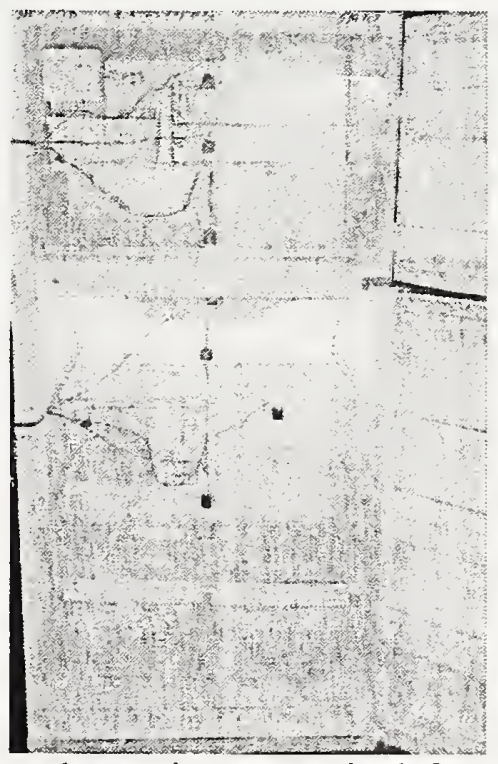

Figure A.5 Top mount domestic automatic defrost refrigerator-freezer Prepared for DOE tests 


\section{ISO Tests}

Voltage input during test:

First Setting: $115.0 \mathrm{~V}, 60 \mathrm{~Hz}$, voltage variance $0.42 \mathrm{~V}$

Second Setting: $115.2 \mathrm{~V}, 60 \mathrm{~Hz}$, voltage variance $0.41 \mathrm{~V}$

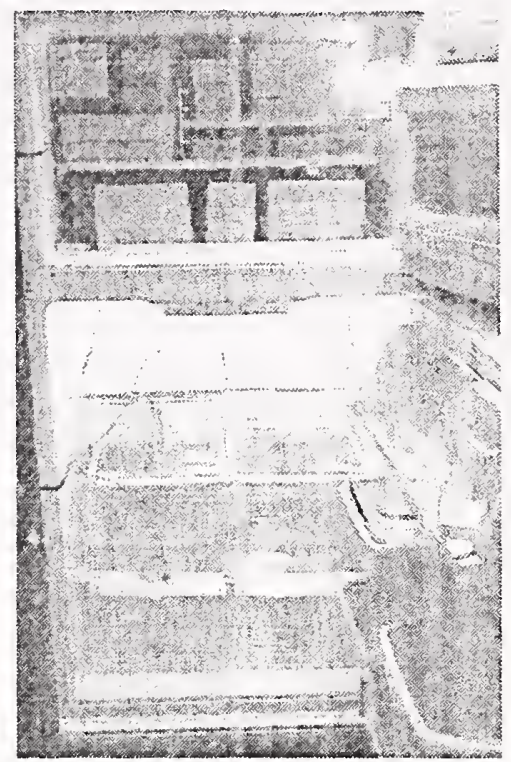

Figure A.6 Top mount domestic automatic defrost refrigerator-freezer Prepared for ISO tests

\section{Defrost Cycle Power for Top Mount Refrigerator-Freezer}

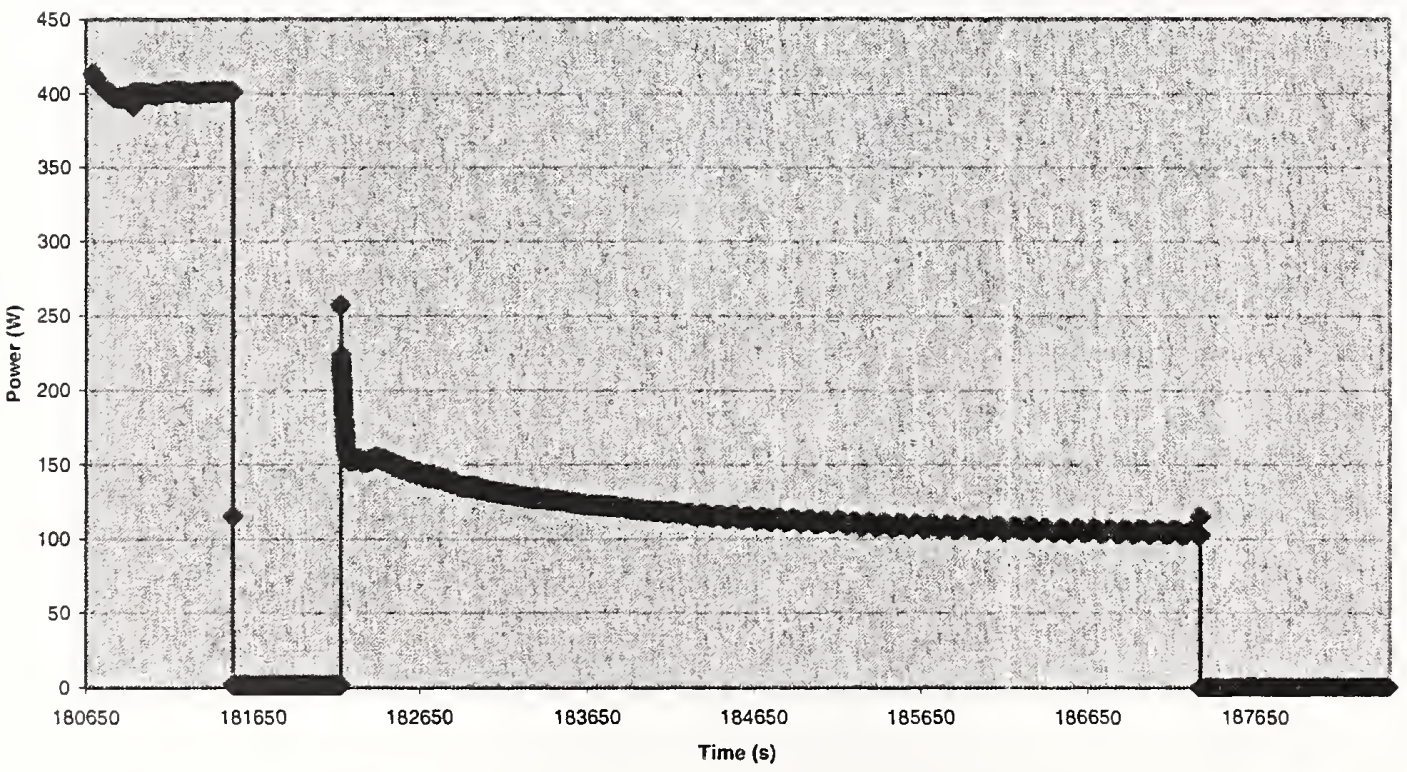

Figure A.7 Top mount domestic automatic defrost refrigerator-freezer Plot of typical energy usage during defrost sequence 
Steady State Operation Power for Top Mount Refrigerator-Freezer

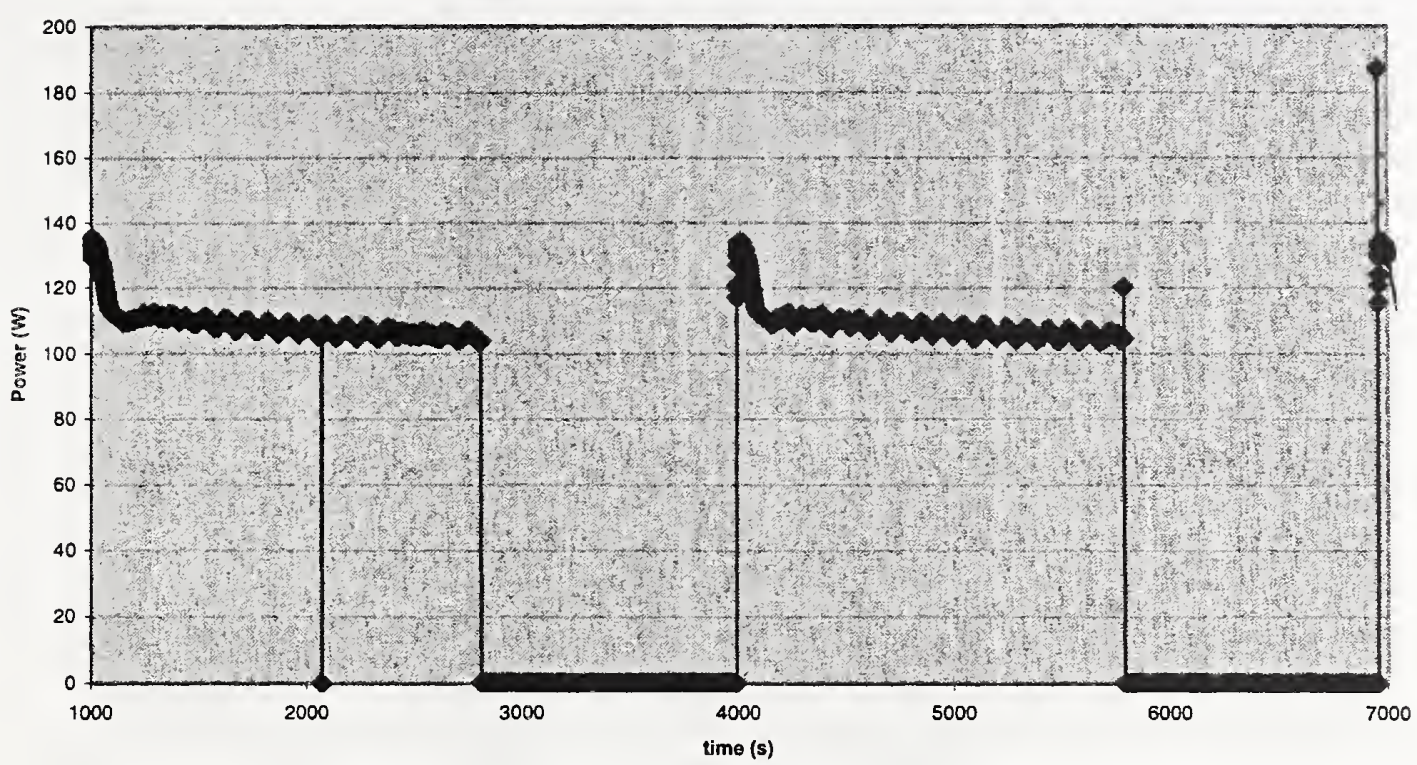

Figure A.8 Top mount domestic automatic defrost refrigerator-freezer Plot of typical energy usage during steady state operation

\section{A.3 Top Mount Domestic Technologically Advanced Refrigerator-Freezer}

\section{DOE Tests}

Voltage input during test:

Median Setting: $115.3 \mathrm{~V}, 60 \mathrm{~Hz}$, voltage variance $0.28 \mathrm{~V}$

Warm Setting: $115.6 \mathrm{~V}, 60 \mathrm{~Hz}$, voltage variance $0.13 \mathrm{~V}$

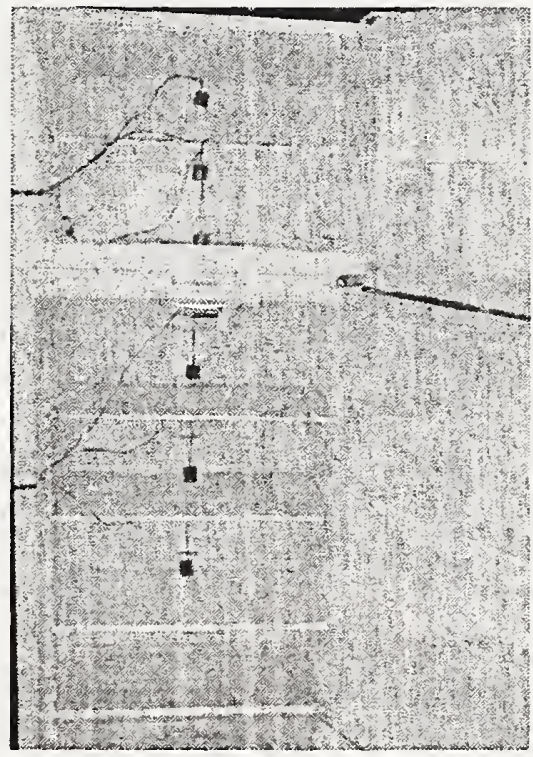

Figure A.9 Top mount technologically advanced refrigerator-freezer

Prepared for DOE tests 


\section{ISO Tests}

Voltage input during test:

First Setting: $115.0 \mathrm{~V}, 60 \mathrm{~Hz}$, voltage variance $0.30 \mathrm{~V}$

Second Setting: $115.1 \mathrm{~V}, 60 \mathrm{~Hz}$, voltage variance $0.20 \mathrm{~V}$

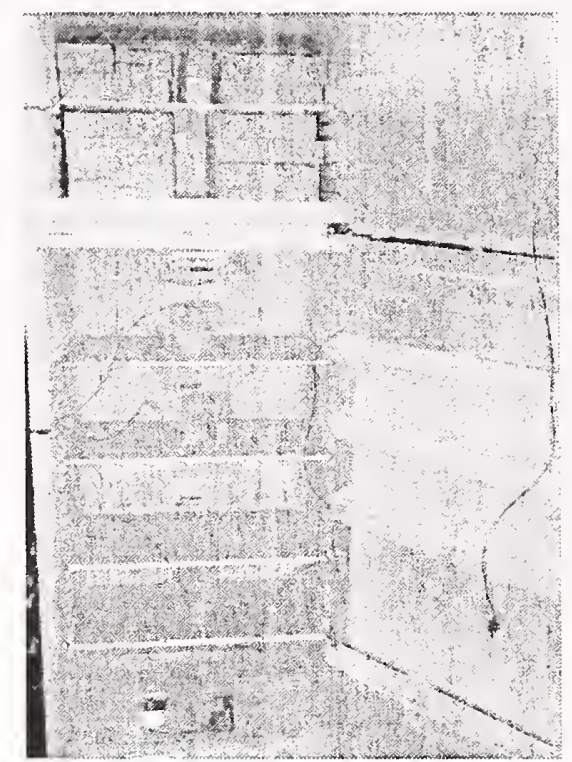

Figure A.10 Top mount technologically advanced refrigerator-freezer Prepared for ISO tests

Defrost Cycle Power for Technologically Advanced Refrigerator-Freezer

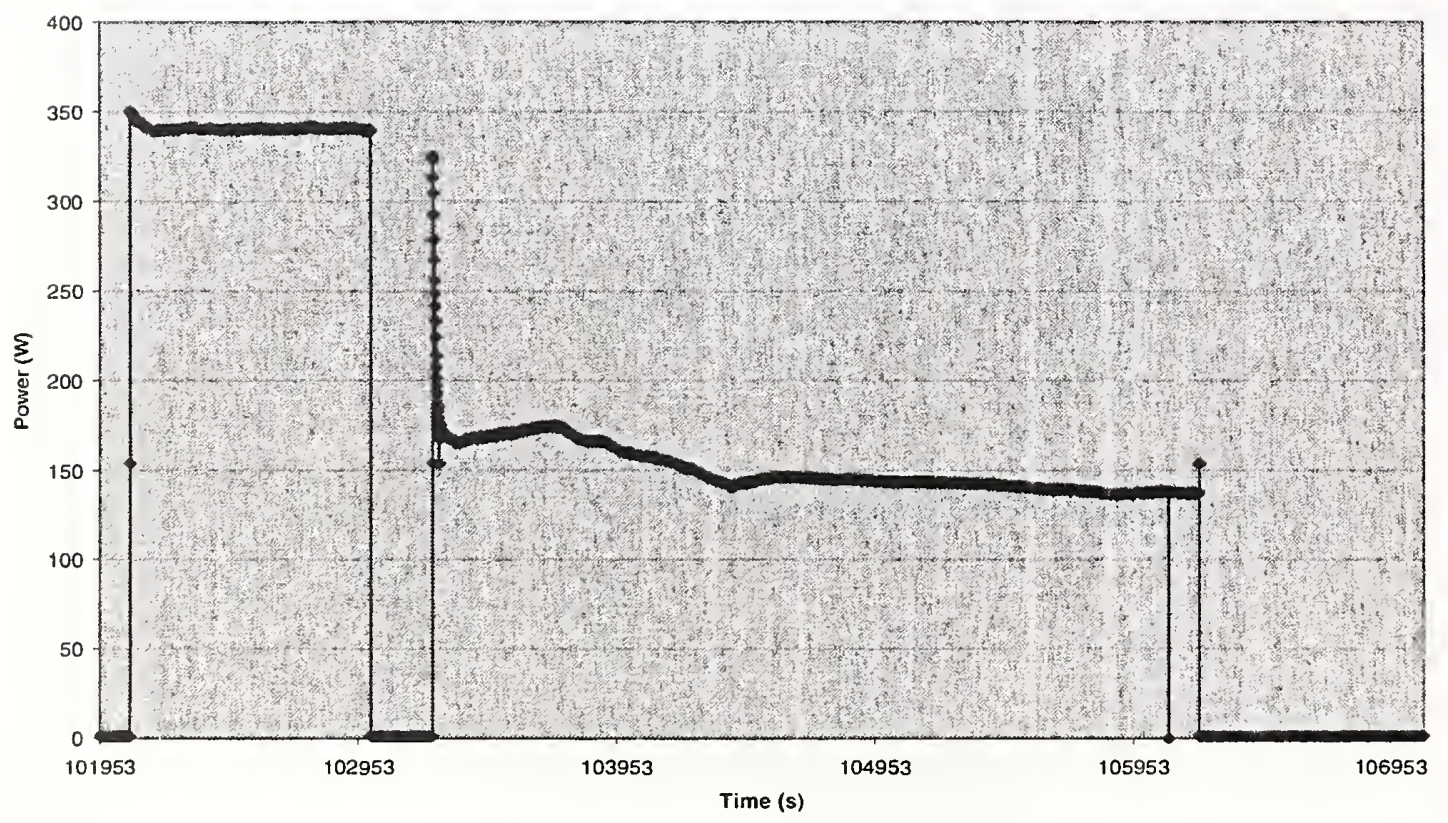

Figure A.11 Top mount technologically advanced refrigerator-freezer Plot of typical energy usage during defrost sequence 


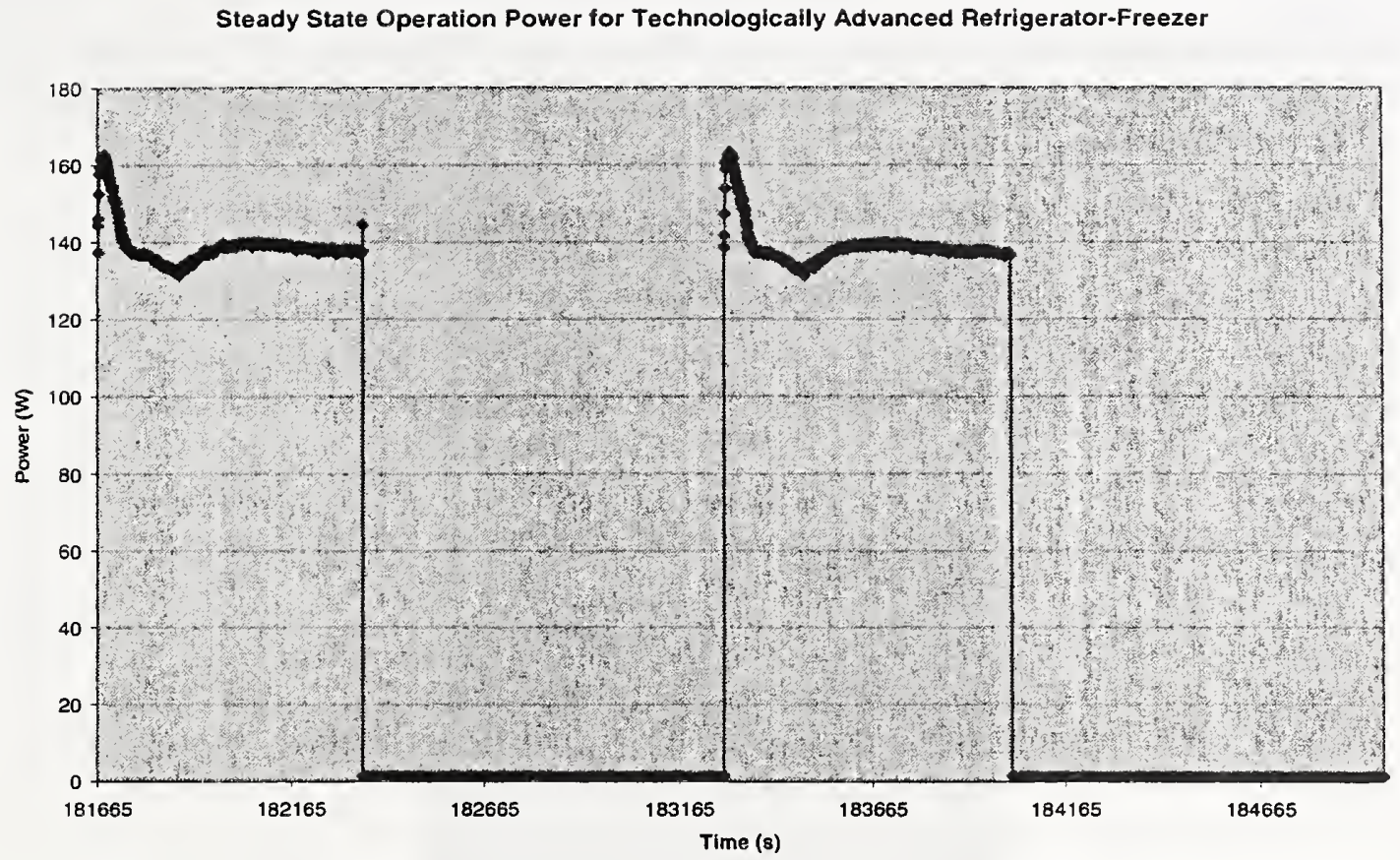

Figure A.12 Top mount technologically advanced refrigerator-freezer

Plot of typical energy usage during steady state operation

\section{A.4 Manual Defrost Refrigerator}

\section{DOE Tests}

Voltage input during test:

Median Setting: $115.2 \mathrm{~V}, 60 \mathrm{~Hz}$, voltage variance $0.16 \mathrm{~V}$

Warm Setting: $115.0 \mathrm{~V}, 60 \mathrm{~Hz}$, voltage variance $0.23 \mathrm{~V}$

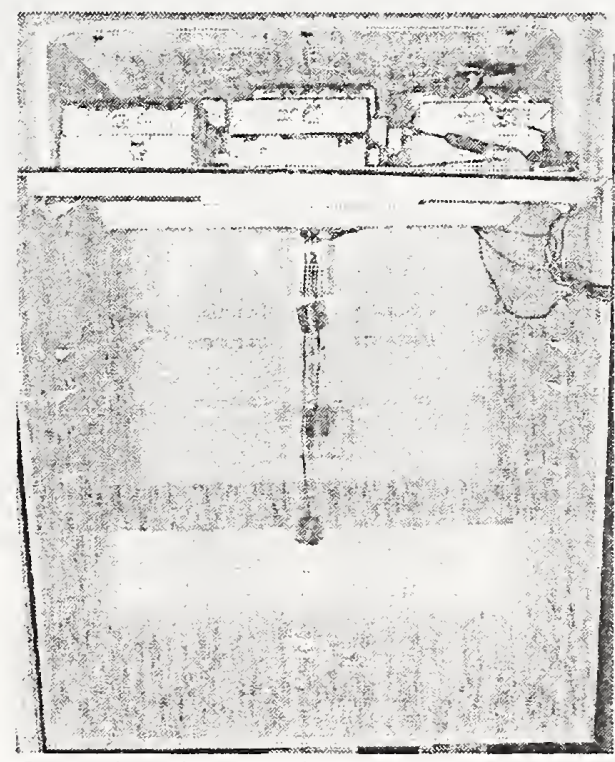

Figure A.13 Manual defrost refrigerator prepared for DOE tests 


\section{ISO Tests}

Voltage input during test:

First Setting: $114.6 \mathrm{~V}, 60 \mathrm{~Hz}$, voltage variance $0.22 \mathrm{~V}$

Second Setting: $114.6 \mathrm{~V}, 60 \mathrm{~Hz}$, voltage variance $0.31 \mathrm{~V}$

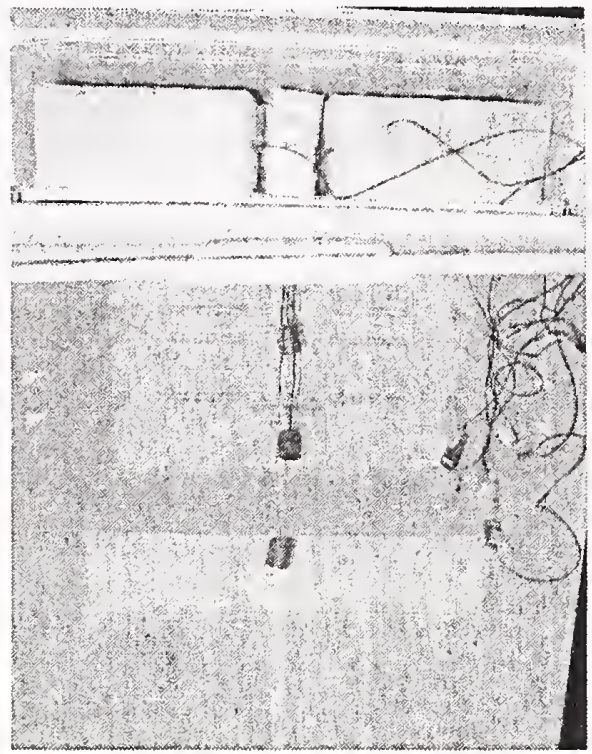

Figure A.14 Manual defrost refrigerator prepared for ISO tests

Steady State Operation Power for Manual Defrost Refrigerator

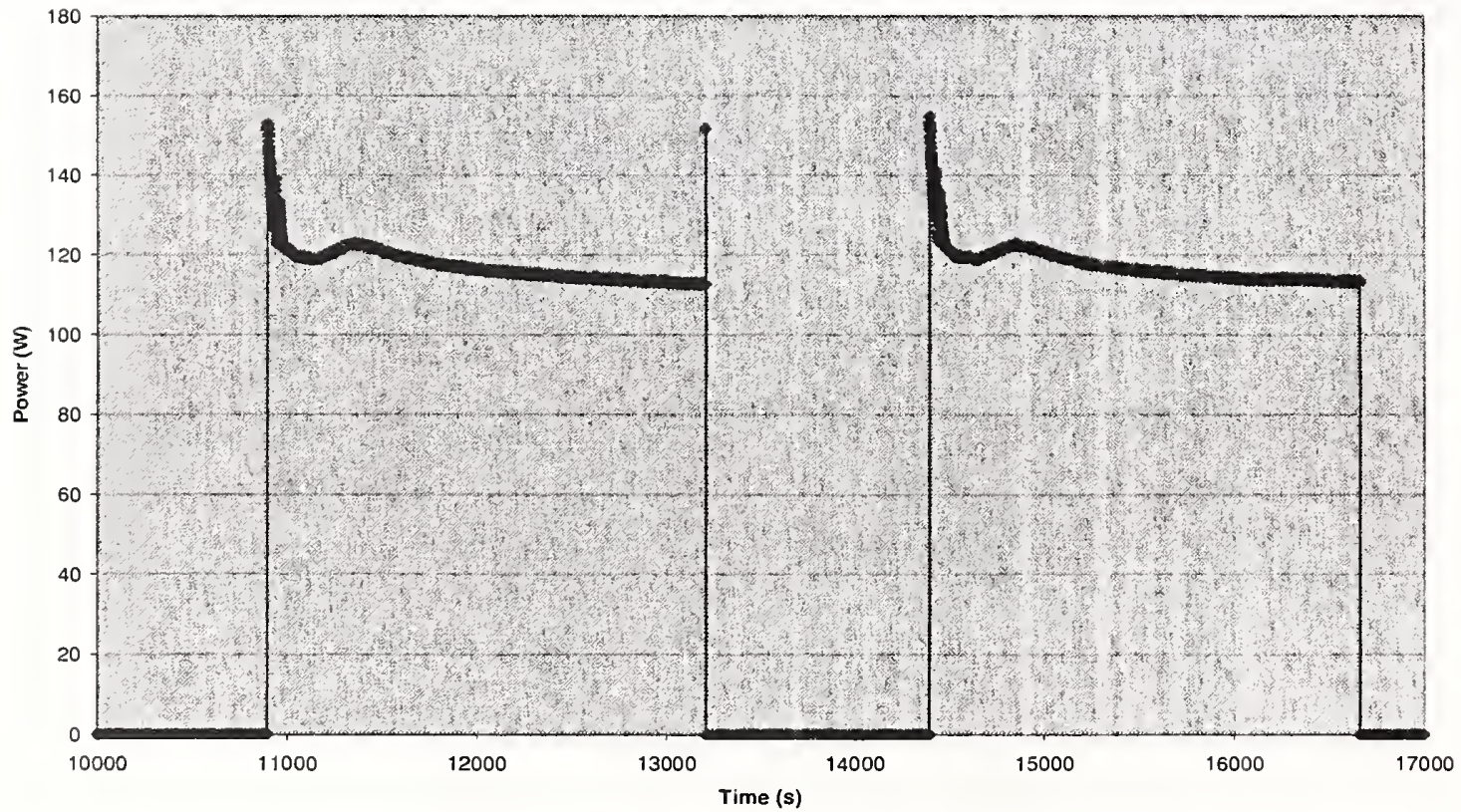

Figure A.15 Manual defrost refrigerator Plot of typical energy usage during steady state operation 


\section{Appendix B: Uncertainty Analysis}

The uncertainty of a quantity, $\mathrm{R}$, calculated from $\mathrm{n}$ independent measurements is a function of the individual uncertainty of each measurement.

$$
R=f\left(x_{1}, x_{2}, \ldots x_{n}\right)
$$

When each measurement, $x_{i}$, has a given uncertainty, $\partial x_{i}$, the maximum uncertainty of $\mathrm{R}$ is given by:

$$
E_{R, \max }=\left|\frac{\partial f}{\partial x_{1}} \partial x_{1}\right|+\left|\frac{\partial f}{\partial x_{2}} \partial x_{2}\right|+\ldots+\left|\frac{\partial f}{\partial x_{n}} \partial x_{n}\right|
$$

The parameter of greater interest is the average (RMS) uncertainty given by:

$$
E_{R}=\sqrt{\left(\frac{\partial f}{\partial x_{1}} \partial x_{1}\right)^{2}+\left(\frac{\partial f}{\partial x_{2}} \partial x_{2}\right)^{2}+\ldots+\left(\frac{\partial f}{\partial x_{n}} \partial x_{n}\right)^{2}}
$$

As was the case for three of the four refrigerators tested in this study, the energy consumption value was determined by interpolating the results of two independent measurements. The equation for determining the energy consumption is as follows:

$$
E=\frac{E_{1}\left(T_{\text {ref }}-T_{2}\right)-E_{2}\left(T_{r e f}-T_{1}\right)}{T_{1}-T_{2}}
$$

Each of the measured quantities affects the value of the energy consumption as follows

$$
\begin{array}{ll}
\frac{\partial E}{\partial T_{1}}=\frac{\left(E_{1}-E_{2}\right)\left(T_{\text {ref }}-T_{2}\right)}{\left(T_{1}-T_{2}\right)^{2}} & \frac{\partial E}{\partial T_{2}}=\frac{\left(E_{1}-E_{2}\right)\left(T_{\text {ref }}-T_{1}\right)}{\left(T_{1}-T_{2}\right)^{2}} \\
\frac{\partial E}{\partial E_{1}}=\frac{\left(T_{\text {ref }}-T_{1}\right)}{\left(T_{1}-T_{2}\right)}+1 & \frac{\partial E}{\partial E_{2}}=\frac{\left(T_{1}-T_{\text {ref }}\right)}{\left(T_{1}-T_{2}\right)}
\end{array}
$$

Therefore, the average uncertainty becomes:

$$
E_{R}=\sqrt{\left(\frac{\partial E}{\partial E_{1}} \partial E_{1}\right)^{2}+\left(\frac{\partial E}{\partial E_{2}} \partial E_{2}\right)^{2}+\left(\frac{\partial E}{\partial T_{1}} \partial T_{1}\right)^{2}+\left(\frac{\partial E}{\partial T_{2}} \partial T_{2}\right)^{2}}
$$


Table B.1 Uncertainty Analysis for Side-By-Side Refrigerator-Freezer

\begin{tabular}{|c|c|c|c|c|}
\hline & \multicolumn{2}{|c|}{ Department of Energy Test } & \multicolumn{2}{|c|}{ ISO 8561} \\
\hline & $\begin{array}{l}\text { Median } \\
\text { Thermostat } \\
\text { Setting }\end{array}$ & $\begin{array}{c}\text { Warmest } \\
\text { Thermostat } \\
\text { Setting }\end{array}$ & $\begin{array}{l}\text { Median } \\
\text { Thermostat } \\
\text { Setting }\end{array}$ & $\begin{array}{c}\text { Warmest } \\
\text { Thermostat } \\
\text { Setting }\end{array}$ \\
\hline $\begin{array}{l}\text { Measured } \\
\text { Energy }\end{array}$ & $2.85 \frac{\mathrm{kW} \cdot \mathrm{h}}{\mathrm{d}}$ & $2.32 \frac{\mathrm{kW} \cdot \mathrm{h}}{\mathrm{d}}$ & $2.03 \frac{\mathrm{kW} \cdot \mathrm{h}}{\mathrm{d}}$ & $1.89 \frac{\mathrm{kW} \cdot \mathrm{h}}{\mathrm{d}}$ \\
\hline $\begin{array}{l}\text { Energy } \\
\text { Uncertainty }\end{array}$ & $\pm 0.0086 \frac{\mathrm{kW} \cdot \mathrm{h}}{\mathrm{d}}$ & $\pm 0.0070 \frac{\mathrm{kW} \cdot \mathrm{h}}{\mathrm{d}}$ & $\pm 0.0061 \frac{\mathrm{kW} \cdot \mathrm{h}}{\mathrm{d}}$ & $\pm 0.0057 \frac{\mathrm{kW} \cdot \mathrm{h}}{\mathrm{d}}$ \\
\hline $\begin{array}{l}\text { Freezer } \\
\text { Temperature }\end{array}$ & $-18.00{ }^{\circ} \mathrm{C}$ & $-12.99^{\circ} \mathrm{C}$ & $-12.99^{\circ} \mathrm{C}$ & $-11.06^{\circ} \mathrm{C}$ \\
\hline $\begin{array}{l}\text { Temperature } \\
\text { Uncertainty }\end{array}$ & $\pm 0.3^{\circ} \mathrm{C}$ & $\pm 0.3^{\circ} \mathrm{C}$ & $\pm 0.3^{\circ} \mathrm{C}$ & $\pm 0.3^{\circ} \mathrm{C}$ \\
\hline $\begin{array}{l}\text { Maximum } \\
\text { Uncertainty }\end{array}$ & 0.031 & $\frac{W \cdot h}{d}$ & 0.218 & $\frac{W \cdot h}{d}$ \\
\hline $\begin{array}{l}\text { RMS } \\
\text { Uncertainty }\end{array}$ & 0.02 & $\frac{\mathrm{kW} \cdot \mathrm{h}}{\mathrm{d}}$ & 0.015 & $\frac{\mathrm{kW} \cdot \mathrm{h}}{\mathrm{d}}$ \\
\hline
\end{tabular}

Since the energy consumption value for the top mounted, refrigerator-freezer was determined through only one test, the uncertainty is determined only by that measurement.

Table B.2 Uncertainty Analysis for Top Mounted Refrigerator-Freezer

\begin{tabular}{|c|c|c|c|c|}
\hline & \multicolumn{2}{|c|}{ Department of Energy Test } & \multicolumn{2}{|c|}{ ISO 8561} \\
\hline & $\begin{array}{l}\text { Median } \\
\text { Thermostat } \\
\text { Setting }\end{array}$ & $\begin{array}{c}\text { Warmest } \\
\text { Thermostat } \\
\text { Setting }\end{array}$ & $\begin{array}{l}\text { Median } \\
\text { Thermostat } \\
\text { Setting }\end{array}$ & $\begin{array}{c}\text { Warmest } \\
\text { Thermostat } \\
\text { Setting }\end{array}$ \\
\hline $\begin{array}{l}\text { Measured } \\
\text { Energy }\end{array}$ & NA & $1.34 \frac{\mathrm{kW} \cdot \mathrm{h}}{\mathrm{d}}$ & NA & $1.06 \frac{\mathrm{kW} \cdot \mathrm{h}}{\mathrm{d}}$ \\
\hline $\begin{array}{l}\text { Energy } \\
\text { Uncertainty }\end{array}$ & NA & $\pm 0.0040 \frac{\mathrm{kW} \cdot \mathrm{h}}{\mathrm{d}}$ & $\mathrm{NA}$ & $\pm 0.0032 \frac{\mathrm{kW} \cdot \mathrm{h}}{\mathrm{d}}$ \\
\hline $\begin{array}{l}\text { Freezer } \\
\text { Temperature }\end{array}$ & $\mathrm{NA}$ & $-17.87^{\circ} \mathrm{C}$ & NA & $-16.54^{\circ} \mathrm{C}$ \\
\hline $\begin{array}{l}\text { Temperature } \\
\text { Uncertainty }\end{array}$ & NA & $\pm 0.3^{\circ} \mathrm{C}$ & NA & $\pm 0.3^{\circ} \mathrm{C}$ \\
\hline Uncertainty & & $\frac{\mathrm{kW} \cdot \mathrm{h}}{\mathrm{d}}$ & & $\frac{\mathrm{kW} \cdot \mathrm{h}}{\mathrm{d}}$ \\
\hline
\end{tabular}


Table B.3 Uncertainty Analysis for Top Mounted Refrigerator-Freezer with Energy

Saving Technologies

\begin{tabular}{|c|c|c|c|c|}
\hline & \multicolumn{2}{|c|}{ Department of Energy Test } & \multicolumn{2}{|c|}{ ISO 8561} \\
\hline & $\begin{array}{l}\text { Median } \\
\text { Thermostat } \\
\text { Setting }\end{array}$ & $\begin{array}{c}\text { Warmest } \\
\text { Thermostat } \\
\text { Setting }\end{array}$ & $\begin{array}{l}\text { Median } \\
\text { Thermostat } \\
\text { Setting }\end{array}$ & $\begin{array}{c}\text { Warmest } \\
\text { Thermostat } \\
\text { Setting }\end{array}$ \\
\hline $\begin{array}{l}\text { Measured } \\
\text { Energy }\end{array}$ & $1.55 \frac{\mathrm{kW} \cdot \mathrm{h}}{\mathrm{d}}$ & $1.32 \frac{\mathrm{kW} \cdot \mathrm{h}}{\mathrm{d}}$ & $1.21 \frac{\mathrm{kW} \cdot \mathrm{h}}{\mathrm{d}}$ & $1.02 \frac{\mathrm{kW} \cdot \mathrm{h}}{\mathrm{d}}$ \\
\hline $\begin{array}{l}\text { Energy } \\
\text { Uncertainty }\end{array}$ & $\pm 0.0047 \frac{\mathrm{kW} \cdot \mathrm{h}}{\mathrm{d}}$ & $\pm 0.0040 \frac{\mathrm{kW} \cdot \mathrm{h}}{\mathrm{d}}$ & $\pm 0.0036 \frac{\mathrm{kW} \cdot \mathrm{h}}{\mathrm{d}}$ & $\pm 0.0031 \frac{\mathrm{kW} \cdot \mathrm{h}}{\mathrm{d}}$ \\
\hline $\begin{array}{l}\text { Freezer } \\
\text { Temperature }\end{array}$ & $-16.93^{\circ} \mathrm{C}$ & $-12.80^{\circ} \mathrm{C}$ & $-13.02{ }^{\circ} \mathrm{C}$ & $-9.84^{\circ} \mathrm{C}$ \\
\hline $\begin{array}{l}\text { Temperature } \\
\text { Uncertainty }\end{array}$ & $\pm 0.3^{\circ} \mathrm{C}$ & $\pm 0.3^{\circ} \mathrm{C}$ & $\pm 0.3^{\circ} \mathrm{C}$ & $\pm 0.3^{\circ} \mathrm{C}$ \\
\hline $\begin{array}{l}\text { Maximum } \\
\text { Uncertainty }\end{array}$ & $0.016 ?$ & $\frac{\mathrm{kW} \cdot \mathrm{h}}{\mathrm{d}}$ & 0.0179 & $\frac{\mathrm{kW} \cdot \mathrm{h}}{\mathrm{d}}$ \\
\hline $\begin{array}{l}\text { RMS } \\
\text { Uncertainty }\end{array}$ & 0.012 & $\frac{\mathrm{kW} \cdot \mathrm{h}}{\mathrm{d}}$ & 0.0137 & $\frac{\mathrm{kW} \cdot \mathrm{h}}{\mathrm{d}}$ \\
\hline
\end{tabular}

Table B.4 Uncertainty Analysis for Manual Defrost Refrigerator

\begin{tabular}{|c|c|c|c|c|}
\hline & \multicolumn{2}{|c|}{ Department of Energy Test } & \multicolumn{2}{|c|}{ ISO 8561} \\
\hline & $\begin{array}{l}\text { Median } \\
\text { Thermostat } \\
\text { Setting }\end{array}$ & $\begin{array}{c}\text { Warmest } \\
\text { Thermostat } \\
\text { Setting }\end{array}$ & $\begin{array}{c}\text { Median } \\
\text { Thermostat } \\
\text { Setting }\end{array}$ & $\begin{array}{c}\text { Coldest } \\
\text { Thermostat } \\
\text { Setting }\end{array}$ \\
\hline $\begin{array}{l}\text { Measured } \\
\text { Energy } \\
\end{array}$ & $1.86 \frac{\mathrm{kW} \cdot \mathrm{h}}{\mathrm{d}}$ & $1.26 \frac{\mathrm{kW} \cdot \mathrm{h}}{\mathrm{d}}$ & $1.28 \frac{\mathrm{kW} \cdot \mathrm{h}}{\mathrm{d}}$ & $1.81 \frac{\mathrm{kW} \cdot \mathrm{h}}{\mathrm{d}}$ \\
\hline $\begin{array}{l}\text { Energy } \\
\text { Uncertainty }\end{array}$ & $\pm 0.0056 \frac{\mathrm{kW} \cdot \mathrm{h}}{\mathrm{d}}$ & $\pm 0.0038 \frac{\mathrm{kW} \cdot \mathrm{h}}{\mathrm{d}}$ & $\pm 0.0038 \frac{\mathrm{kW} \cdot \mathrm{h}}{\mathrm{d}}$ & $\pm 0.0054 \frac{\mathrm{kW} \cdot \mathrm{h}}{\mathrm{d}}$ \\
\hline $\begin{array}{l}\text { Refrigerator } \\
\text { Temperature }\end{array}$ & $6.20^{\circ} \mathrm{C}$ & $12.61{ }^{\circ} \mathrm{C}$ & $5.36^{\circ} \mathrm{C}$ & $-0.01{ }^{\circ} \mathrm{C}$ \\
\hline $\begin{array}{l}\text { Temperature } \\
\text { Uncertainty }\end{array}$ & $\pm 0.3^{\circ} \mathrm{C}$ & $\pm 0.3^{\circ} \mathrm{C}$ & $\pm 0.3^{\circ} \mathrm{C}$ & $\pm 0.3^{\circ} \mathrm{C}$ \\
\hline $\begin{array}{l}\text { Maximum } \\
\text { Uncertainty }\end{array}$ & 0.028 & $\frac{\mathrm{kW} \cdot \mathrm{h}}{\mathrm{d}}$ & 0.0296 & $\frac{\mathrm{kW} \cdot \mathrm{h}}{\mathrm{d}}$ \\
\hline $\begin{array}{l}\text { RMS } \\
\text { Uncertainty }\end{array}$ & 0.024 & $\frac{\mathrm{kW} \cdot \mathrm{h}}{\mathrm{d}}$ & 0.0279 & $\frac{\mathrm{kW} \cdot \mathrm{h}}{\mathrm{d}}$ \\
\hline
\end{tabular}




